\title{
Immunotherapy for Gastrointestinal Malignancies
}

\author{
Diwakar Davar, Weijing Sun* \\ Division of Hematology-Oncology, Department of Medicine, University of Pittsburgh School of Medicine, \\ Pittsburgh, USA \\ Email: $\underline{\text { sunw@upmc.edu }}$
}

Received 28 April 2014; revised 20 May 2014; accepted 26 May 2014

Copyright (C) 2014 by authors and Scientific Research Publishing Inc.

This work is licensed under the Creative Commons Attribution International License (CC BY).

http://creativecommons.org/licenses/by/4.0/

(c) (i) Open Access

\begin{abstract}
Gastrointestinal (GI) malignancies (esophageal, gastric, pancreatic, intra- and extra-biliary ductal, hepatocellular, and colorectal cancers) are an important cause of cancer incidence and mortality in the US and globally. GI cancers account for $15.4 \%$ and $23.8 \%$ of incident cancers and cancerrelated deaths respectively in the US alone. Although earlier diagnosis and treatment advances have improved outcomes for some GI malignancies, the need for improved therapies in all disease phases (adjuvant, neoadjuvant and advanced) is paramount. Utilization of monoclonal antibodies targeting against vascular endothelial growth factor (VEGF) and epidermal growth factor receptor (EGFR) has shown the success in selected colorectal carcinoma patients. More investigations of immunotherapy are on going in the treatment of GI malignances with different mechanisms and methods. In this article, we review data for established and evolving immunotherapy-related treatment options in GI malignancies.
\end{abstract}

\section{Keywords}

Colorectal Carcinoma, Gastric Carcinoma, Pancreatic Carcinoma, Hepatocellular Carcinoma, Gallbladder and Biliary Duct Carcinoma, Advanced, Metastatic, Immunotherapy, Vaccine, Monoclonal Antibody

\section{Introduction}

Gastrointestinal (GI) malignancies refer to malignant neoplasms of the GI tract and accessory organs of digestion system: esophagus, stomach, liver and biliary system, pancreas, small intestine, colon and rectum, appendix and anus. Overall, GI malignancies account for more incident cases and deaths than any other organ system. However, these cancers are highly disparate: involving tumors of various histological types (e.g. adenocarcino-

*Corresponding author. 
ma vs. squamous carcinoma and others) and subtypes with vastly different incidences, lifetime risks and outcomes as outlined in Table 1.

The primary intently curative treatment option for most GI malignancies is still surgical resection though combined modality therapy (concurrent chemotherapy and radiotherapy) has equivalent outcomes in anal cancer. Adjuvant and/or neoadjuvant chemotherapy or chemoradiotherapy has been shown to improve overall survival in select populations. However, given the absence of a proven screening modality in malignancies other than colonoscopy in colorectal cancer, most patients with cancers from GI system are diagnosed at an advanced stage. Effective screening modalities for cancers and discovering active chemotherapeutic, biologic agents in advanced disease are both areas of active investigational efforts in GI malignancies.

Unlike melanoma and renal cell cancer in which immunotherapeutic options were a focus of early efforts, similar approaches in GI malignancies have only recently been exploited likely secondary to early successes with cytotoxic chemotherapy. However, observations support exploring immunotherapeutic modalities in GI malignancies: tumor associated antigens (TAA) associated with tumor-specific immune responses in esophageal (MAGE-A3/4 and NYESO-1), gastric (Her-2/neu), pancreatic (MUC1 and mesothelin), hepatocellular (AFP, GPC3, NY-ESO-1, SSX-2, MAGE-A and TERT) and colorectal (CEA) malignancies [1]-[12]; tumor-specific cytotoxic T-cells higher levels of which correlate with improved prognosis [13] [14]; and T-cell inhibitory factors [CD4+ Foxp3+ regulatory T-cells (Tregs) and myeloid-derived suppressor cells (MDSCs)] higher levels of which correlate with poorer prognosis [15] [16]. In this article, we broadly delineate the various immunotherapeutic options that have been or are explored in GI malignancies.

\section{Monoclonal Antibody Mediated Targeted Therapy}

\subsection{EGFR Inhibition: Cetuximab (Erbitux ${ }^{\circledR}$ ) and Panitumumab (Vectibix ${ }^{\circledR}$ )}

Epidermal growth factor receptor (EGFR) mediated signaling plays important roles in colorectal cancer (CRC) initiation and progression making EGFR inhibition an attractive target. There have been extensive studies in CRC regarding the efficacy, appropriate subpopulation and toxicity. However, limited studies have been pursued in esophageal, gastric, pancreatico-biliary and/or hepatocellular carcinomas.

EGFR engages several downstream signaling cascades including PI3K (PI3K/AKT/mTOR) and MAP kinase (RAS/RAF/MEK/ERK) pathways which mediate cell differentiation, proliferation, and survival. RAS is a membrane bound protein which exchanges bound GDP for GTP and has intrinsic GTPase activity which ensures selfinactivation by GTP hydrolysis. RAS couples growth factor receptors to intracellular signaling pathways by activating downstream targets such as RAF, ERK1, ERK2 and PI3K that promote cell proliferation [17]. Three human RAS genes have been identified: HRAS, KRAS, and NRAS. Oncogenic KRAS typically contain single amino acid substitutions (most frequently, in codons 12/13/61) that produce KRAS proteins with strongly reduced intrinsic GTPase activity resulting in constitutively activated GTP-bound state. Activating KRAS mutations are instrumental in the growth and proliferation of a wide variety of tumor types including melanoma, lung, CRC, thyroid and pancreatic carcinomas with a prevalence ranking from $11 \%$ (melanoma) to $95 \%$ (pancreatic adenocarcinoma) [18]. Uniquely in CRC, the chronological sequence of mutations during the tumorigenic pro-

Table 1. Incidence and survival in GI malignancies.

\begin{tabular}{ccccccc}
\hline & $\begin{array}{c}\text { Cases in } 2013 \text { (\% of } \\
\text { New Cancer Cases) }\end{array}$ & $\begin{array}{c}\text { Incidence of New Cases } \\
\text { (per 100,000 population, } \\
\text { 2006-2010) }\end{array}$ & $\begin{array}{c}\text { Deaths in 2013 (\% } \\
\text { of Cancer Deaths) }\end{array}$ & $\begin{array}{c}\text { Death Incidence (per } \\
\text { 100,000 population, } \\
\text { 2006-2010) }\end{array}$ & $\begin{array}{c}\text { 5-Year Survival } \\
\text { (\%, 2003-2009) }\end{array}$ & $\begin{array}{c}\text { Lifetime } \\
\text { Risk }\end{array}$ \\
\hline $\begin{array}{c}\text { Colo-Rectal Cancer } \\
\text { Pancreatic }\end{array}$ & $142,820(8.6 \%)$ & 45.0 & $50,830(8.8 \%)$ & 16.4 & $64.9 \%$ & $4.8 \%$ \\
$\begin{array}{c}\text { Liver and Bile Duct } \\
\text { (intra-hepatic) }\end{array}$ & $45,220(2.7 \%)$ & 12.2 & $38,460(6.6 \%)$ & 10.9 & $6.0 \%$ & $1.5 \%$ \\
$\quad \begin{array}{c}\text { Esophageal } \\
\text { Small Intestine }\end{array}$ & $17,990(1.1 \%)$ & 7.7 & $21,670(3.7 \%)$ & 5.6 & $16.1 \%$ & $0.9 \%$ \\
Anal & $8810(0.5 \%)$ & 4.4 & $15,210(2.6 \%)$ & 4.3 & $17.3 \%$ & $0.5 \%$ \\
\hline
\end{tabular}

Surveillance, Epidemiology, and End Results (SEER) Program (www.seer.cancer.gov) SEER*Stat Database: Mortality—All COD, Aggregated with State, Total US (1969-2010), National Cancer Institute, DCCPS, Surveillance Research Program, Surveillance Systems Branch, released April 2013, accessed March 30, 2014. Underlying mortality data provided by NCHS (www.cdc.gov/nchs). 
cess determines the eventual phenotype [19].

Cetuximab (a mouse/human chimeric, IgG1) and panitumumab (a full human, IgG2) are anti-EGFR monoclonal antibodies (MoAb) that competitively inhibit ligand-receptor binding and GTP phosphorylating, effectively disrupting downstream signaling. Additionally, given IgG1 isotype, cetuximab may activate complement pathway and mediate antibody-dependent cellular cytotoxicity (ADCC). Early phase studies of EGFR inhibition in CRC yielded positive results and prompted phase III studies [20]-[40]. Given KRAS' role in mediating EGFR signaling, it was postulated that gain of function mutations would result in constitutively activated KRAS and consequent loss of sensitivity to EGFR inhibition in colorectal carcinoma. Proof of concept was initially provided by retrospective analysis of the NCIC CTG/AGITG CO17 phase III trial. KRAS mutation status was determined in $68.9 \%$ of the original cohort, and was fortuitously well-balanced in both arms. Authors reported KRAS mutant patients did not benefit from cetuximab, while KRAS wild type (WT) patients had significantly improved PFS/OS [20] [21]. This observation was buttressed by analyses of the CRYSTAL and OPUS studies [26]. Other published data supports a lower rate of response to EGFR inhibition in patients with BRAF/ NRAS/HRAS mutations or activating mutations of PIK3CA pathway [41]. The FDA and EMA recommend that EGFR inhibitors be utilized only in KRAS WT patients, and NCCN guideline recommends further that EGFR inhibitorsshould only be considered in mCRC patients with KRAS and NRAS WT [42].

Cetuximab was the first EGFR inhibitor to be approved by the Food and Drug Administration (FDA) and European Medicine Agency (EMA) both as a single agent in relapsed/refractory colorectal carcinomaand together with combination chemotherapy in the 1st line setting on the basis of several randomized phase III studies. Similar results have been observed with panitumumab subsequently. These results are discussed below and depicted in Table 2.

Since agents targeting both EGFR (cetuximab and panitumumab) and vascular endothelial growth factor (VEGF) (bevacizumab, ziv-aflibercept) have gained regulatory approval for KRAS/NRAS WT mCRCpatients, the sequence of application of either agent has been in debate. FIRE-3, a phase III randomizedstudy, compared FOLFIRI/cetuximab to FOLFIRI/bevacizumab in 592 KRAS WT patients as the first line therapy. Overall response rate (ORR) and median progression-free survival (mPFS) were similar in both arms, however, the median overall-all survival (mOS) was significantly prolonged with the arm with cetuximabfirst compared to the arm with bevacizumabfirst (28.7 vs. 25.0 months respectively) despite greater treatment intensity in the bevacizumab arm [31]. Whether the improved mOS observed was related to cetuximab itself or post-progression therapy remains unclear as final results have yet to be published. CALGB/SWOG C80405 is a randomized phase III study of standard chemotherapy regimens (FOLFOX or FOLFIRI) in combination with either bevacizumab or cetuximab in KRAS WT patients as the first line therapy that completed accrual in 2012, the results of which may clarify this issue.

Depending on whether patients were initially treated with a regimen with an oxaliplatin-backbone (FOLFOX/ XELOX) or an irinotecan-backbone (FOLFIRI/XELIRI), 2nd line therapy typically involves a switch between backbones. In KRAS/NRAS WT patients who did not received 1st line EGFR inhibition, adding either cetuximab or panitumumab is advised. There is no data to guide decision making between cetuximab and panitumumab though the higher rate of cetuximab-related infusion reactions in certain geographical regions (in tandem with increased rates of atopy) is a practical consideration [43]. In KRAS/NRAS WT patients who received 1st line EGFR inhibition (either cetuximab or panitumumab), this is typically not continued at the time of progression as cross-resistance is assumed given the similar mechanisms of action. Minimal data is available to address this issue: two clinical trials of panitumumab use in KRAS WT patients who progressed on cetuximab containing regimens arrived at divergent conclusions [44] [45].

Somatic mutations in KRAS ( $<5 \%-10 \%)$ and BRAF (2\%) are unusual events in esophageal and gastric cancers [46]. Non-randomized studies suggested added RFS/OS/RR benefit when cetuximab was added to conventional chemotherapy in advanced esophagogastric cancer. However, this was not borne out in 2 phase III randomized trials of gastric cancer (EXPAND) and esophagogastric cancer (REAL-3) (see Table 2) [34] [40]. The role of adjuvant EGFR inhibition in advanced esophagogastric cancer is being evaluated in a NCI non-randomized phase II study (NCT01360086, perioperative cisplatin/5-FU with cetuximab).

Although phase II studies in unselected populations were promising, the S0205 phase III study of cetuximab in advanced pancreatic cancer was negative [35]. However, both cetuximab and panitumumabin combination with cytotoxic agents have demonstrated benefit in several phase II studies in advancedcholangiocarcinoma [47][50].

Initial phase II studies demonstrated tolerability of cetuximab when added to chemotherapy in HCC [51] [52]. 
Table 2. Published phase III trials of monoclonal antibodies in GI malignancies.

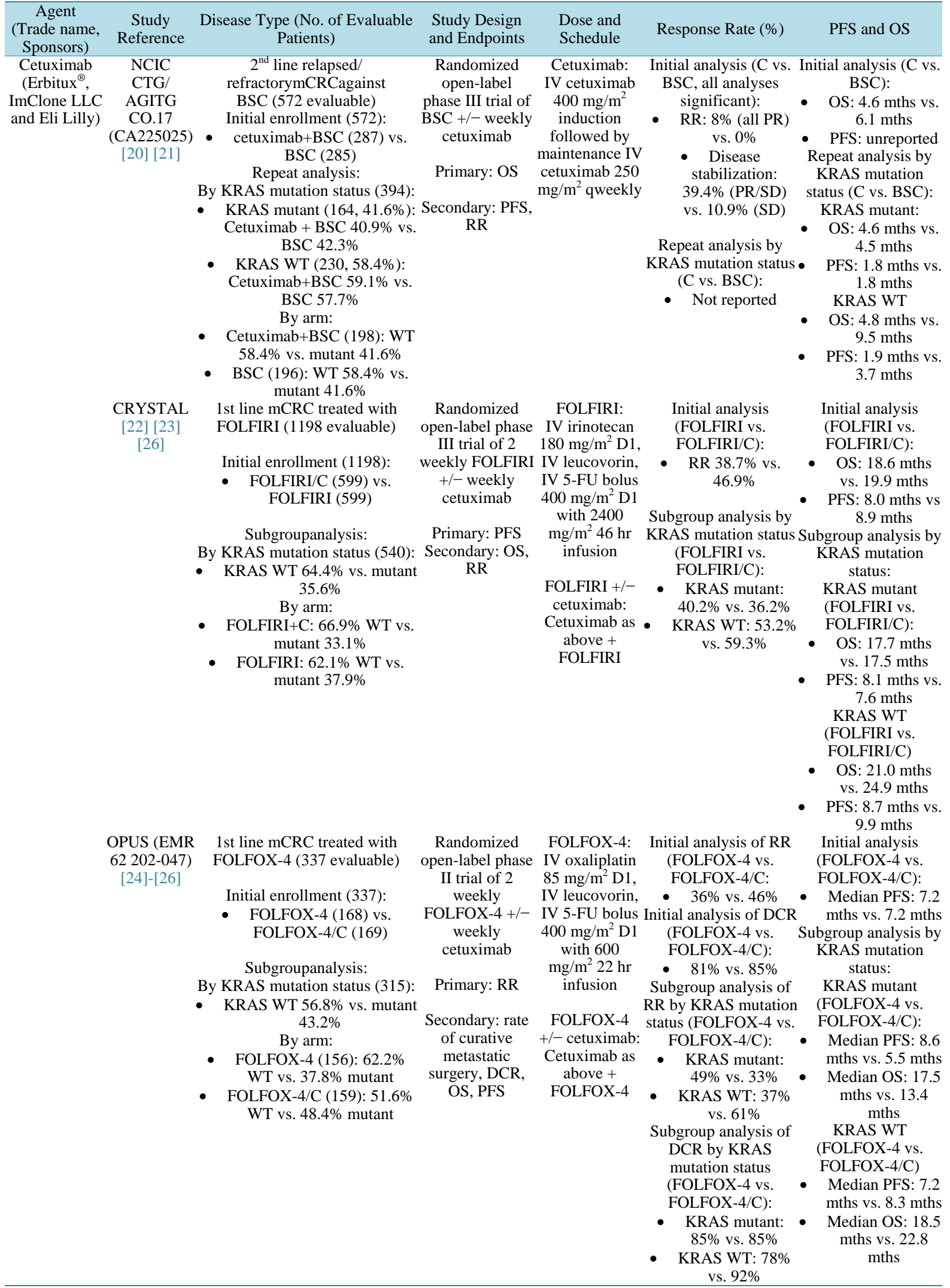




\section{Continued}

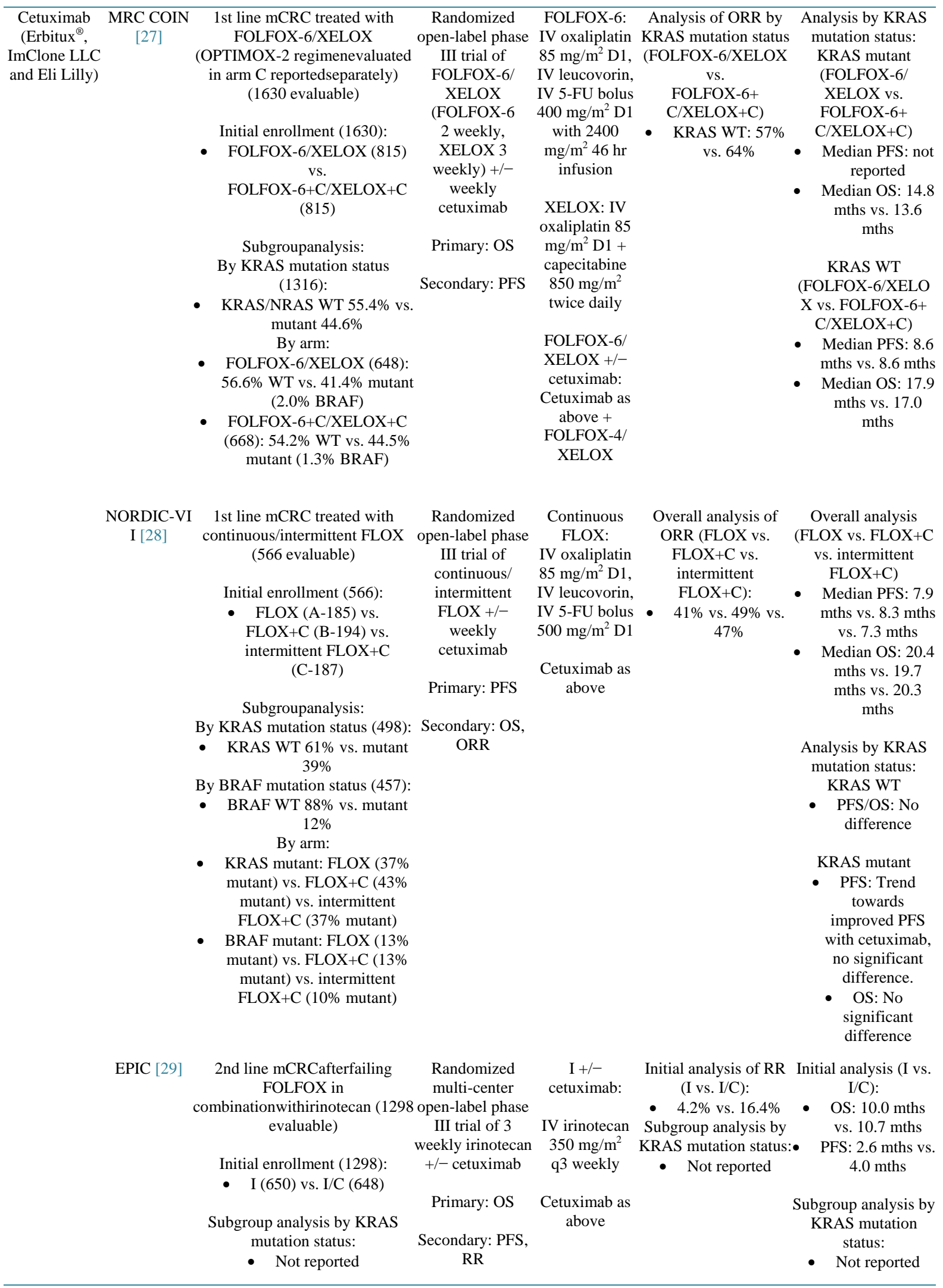




\section{Continued}

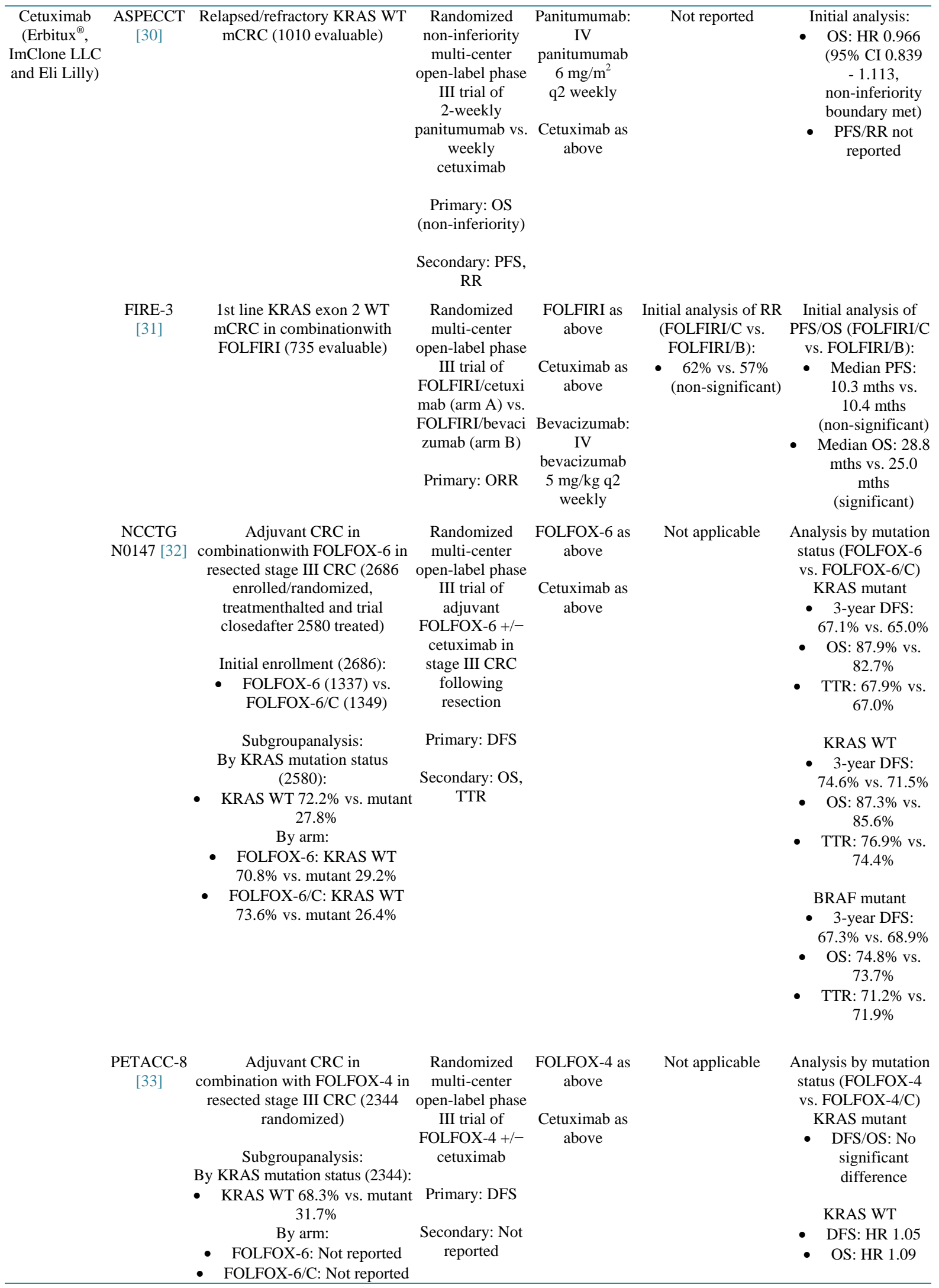




\section{Continued}

Panitumumab Van Cutsem Illumina and Amgen)

$\begin{array}{cc}\text { EXPAND } & \text { 1st line advancedgastric cancer } \\ \text { [34] } & \text { in combination with } \\ \text { cisplatin/capecitabine (882 } \\ \text { evaluable) }\end{array}$

S0205

[35]

- FOLFOX-4/P: KRAS WT (59.5\%) vs. KRAS mutant (40.5\%)

181 [38] $\quad 2^{\text {nd }}$ line relapsed/refractory mCRC after failing priorchemotherapy (1186 evaluable)

Initial enrollment (1186):

- FOLFIRI (595)

- $\quad$ FOLFIRI/P (591)

By KRAS mutation status (1083):

- FOLFIRI (542)

- FOLFIRI/P (541) By arm:

- FOLFIRI: KRAS WT

(54.2\%) vs. KRAS mutant (45.8\%)

- FOLFIRI/P: KRAS WT (56.0\%) vs. KRAS mutant

\section{Randomized}

multi-center

open-label phase

III trial of

cisplatin/capecita

bine (CX) +/-

cetuximab

Primary: PFS

Secondary: OS,

$$
\text { RR }
$$

Randomized Gemcitabine: Initial analysis of RR Initial analysis of

multi-center IV gemcitabine (G vs. G/C): PFS/OS (G vs. G/C):

- RR (CR/PR): $14 \%$ Median PFS: 3

III trial of weekly 7-on,

gemcitabine $(\mathrm{G})$
$+/-$ cetuximab

Primary: OS

\section{Cetuximab as} above

Secondary: OR,

$$
\text { PFS }
$$

Randomized open-label phase

III trial of BSC + - 2-weekly

panitumumab

Primary: PFS

Panitumumab: Initial analysis (BSC Initial analysis (BSC IV $\quad$ vs. P): $\quad$ vs. P): panitumumab - RR: $0 \%$ vs. $10 \% \quad$ OS: HR 1.00 $6 \mathrm{mg} / \mathrm{m}^{2} \quad$ (all PR) $\quad$ PFS: 8 weeks vs. q2 weekly $\quad$ DCR: $10 \%$ (SD) 7.3 weeks vs. $27 \%(\mathrm{PR} / \mathrm{SD})$

Secondary: RR, OS

Randomized multi-center open-label phase

FOLFOX-4 + - P:

FOLFOX-4 as

III trial of 1st line above

FOLFOX-4 vs.

FOLFOX-4/P

Primary: PFS

Panitumumab as above

vs. $12 \%$ mths vs. 3.4 mths

- DCR

- Median OS: 5.9

(CR/PR/SD): 30\% mths vs. $6.3 \mathrm{mths}$

Secondary: OS, ORR

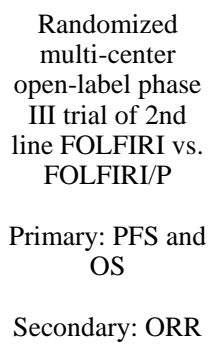

Analysis by KRAS mutation status (FOLFOX-4 vs. FOLFOX-4/P):

- KRAS mutant: $48 \%$ vs. $55 \%$ KRAS WT: $40 \%$ vs. $40 \%$
Analysis by KRAS mutation status (FOLFOX-4 vs. FOLFOX-4/P): KRAS mutant:

- Median OS: 19.3 mths vs. 15.5 mths

- $\quad$ Median PFS: 8.8 mths vs. 7.3 mths

KRAS WT:

- Median OS: 19.7 mths vs. 23.9 mths

- $\quad$ Median PFS: 8.0 mths vs. 9.6 mths

Analysis by KRAS mutation status (FOLFIRI vs. FOLFIRI/P):

KRAS mutant: FOLFIRI/P):

KRAS mutant: $35 \%$ vs. $10 \%$

- Median OS: 11.1 mths vs. 11.8

Vs. $14 \%$ mths mths vs. 5.0 mths

KRAS WT:

- Median OS: 12.5 mths vs. 14.5 mths

- $\quad$ Median PFS: 3.9 mths vs. 5.9 mths
- $\quad$ Median PFS: 4.9 


\section{Continued}

\begin{tabular}{|c|c|c|c|c|c|c|}
\hline \multirow[t]{4}{*}{$\begin{array}{l}\text { Panitumumab } \\
\text { (Vectibix }^{\circledR} \text {, } \\
\text { Illumina and } \\
\text { Amgen) }\end{array}$} & $\begin{array}{c}\text { PICCOLO } \\
\text { [39] }\end{array}$ & $\begin{array}{c}\text { 2nd line mCRCafterfailing 5-FU } \\
\text { and/oroxaliplatin in } \\
\text { combination with irinotecan in } \\
\text { KRAS WT patients (460 } \\
\text { evaluable) } \\
\text { Initial enrollment (460): } \\
\text { - I (230) vs. I/P (230) }\end{array}$ & $\begin{array}{c}\text { Randomized } \\
\text { multi-center } \\
\text { open-label phase } \\
\text { III trial of 2nd } \\
\text { line irinotecan } \\
+/- \\
\text { panitumumab } \\
\text { in KRAS WT } \\
\text { patients } \\
\text { Primary: OS }\end{array}$ & $\begin{array}{l}\text { I:IV irinotecan } \\
350 \mathrm{mg} / \mathrm{m}^{2} \\
\text { q3 weekly } \\
\text { Panitumumab: } \\
\text { IV } \\
\text { panitumumab } \\
9 \mathrm{mg} / \mathrm{m}^{2} \\
\text { q3 weekly }\end{array}$ & $\begin{array}{c}\text { Analysis (I vs. I/P): } \\
\text { - } \quad \text { RR: OR of } \\
\text { response } 4.12\end{array}$ & $\begin{array}{c}\text { Analysis (I vs. I/P): } \\
\text { Primary OS } \\
\text { analysis after } \\
246 \text { deaths: } 10.5 \\
\text { mths vs. } 10.4 \\
\text { mths } \\
\text { - } \quad \text { Final OS } \\
\text { analysis: } 10.9 \\
\text { mths vs. } 10.4 \\
\text { mths } \\
\text { - } \quad \text { PFS: HR } 0.78\end{array}$ \\
\hline & & & $\begin{array}{c}\text { Secondary: PFS, } \\
\text { RR }\end{array}$ & & & \\
\hline & $\begin{array}{c}\text { REAL3 } \\
{[40]}\end{array}$ & $\begin{array}{c}\text { 1st line advance } \\
\text { desophagealadenoCA in } \\
\text { combination with EOC (553 } \\
\text { evaluable) } \\
\text { Initial enrollment (553): } \\
\text { - EOC (275) vs. EOC/P (278) }\end{array}$ & $\begin{array}{c}\text { Randomized } \\
\text { multi-center } \\
\text { open-label phase } \\
\text { III trial of 1st line } \\
\text { EOC +/- } \\
\text { panitumumab } \\
\text { Primary: OS } \\
\text { Secondary: PFS, } \\
\text { RR }\end{array}$ & $\begin{array}{c}\text { EOC: IV } \\
\text { epirubicin } 50 \\
\mathrm{mg} / \mathrm{m}^{2} \mathrm{D} 1, \mathrm{IV} \\
\text { oxaliplatin } \\
100 \mathrm{mg} / \mathrm{m}^{2} \mathrm{D} 1 \text {, } \\
\text { oral } \\
\text { capecitabine } \\
1000 \mathrm{mg} / \mathrm{m}^{2} \\
\text { twice daily } \\
\text { D1-D21 } \\
\text { Panitumumab: } \\
\text { IV } \\
\text { panitumumab } \\
9 \mathrm{mg} / \mathrm{m}^{2} \\
\text { q3 weekly }\end{array}$ & $\begin{array}{l}\text { Analysis (EOC vs. } \\
\text { EOC/P): } \\
\text { - } \quad \text { RR: } 42 \% \text { vs. } 46 \% \\
\bullet\end{array}$ & $\begin{array}{l}\text { Analysis (EOC vs. } \\
\text { EOC/P): } \\
\text { PFS: } 7.4 \text { mths vs. } \\
\text { 6.0mths } \\
\text { 1-year PFS: } 21 \% \\
\text { vs. } 20 \% \\
\text { OS analysis after } \\
251 \text { deaths: } 11.3 \\
\text { mths vs. } 8.8 \text { mths } \\
\text { 1-year OS: } 46 \% \\
\text { vs. } 33 \%\end{array}$ \\
\hline & $\begin{array}{c}\text { ASPECCT } \\
{[30]}\end{array}$ & & & Seeabove & & \\
\hline \multirow[t]{2}{*}{$\begin{array}{l}\text { Bevacizumab } \\
\text { (Avastin }^{\circledR}, \\
\text { Genentech) }\end{array}$} & $\begin{array}{l}\text { Hurwitz } \\
\text { et al. } \\
\text { [56] [57] }\end{array}$ & $\begin{array}{l}\text { 1st line mCRC in combination } \\
\text { with IFL (813 evaluable) } \\
\text { Initial enrollment (813): } \\
\text { - IFL/placebo (402) vs. IFL/B } \\
\text { (411) }\end{array}$ & $\begin{array}{c}\text { Randomized } \\
\text { multi-center } \\
\text { placebo- } \\
\text { controlled phase } \\
\text { III trial of 1st line } \\
\text { IFL +/- } \\
\text { bevacizumab } \\
\text { Primary: OS } \\
\text { Secondary: PFS, } \\
\text { RR }\end{array}$ & $\begin{array}{l}\text { IFL (given } \\
\text { weekly for } 4 \\
\text { weeks, cycles } \\
\text { repeat } \\
\text { q6weekly: } \\
\text { IV irinotecan } \\
125 \mathrm{mg} / \mathrm{m}^{2} \\
\text { qweekly, IV } \\
5 \text {-FU } 500 \\
\mathrm{mg} / \mathrm{m}^{2} \\
\text { qweekly, IV } \\
\text { leucovorin } \\
20 \mathrm{mg} / \mathrm{m}^{2} \\
\text { qweekly } \\
\\
\text { Bevacizumab: } \\
\text { IV } \\
\text { bevacizumab } \\
5 \mathrm{mg} / \mathrm{m}^{2} \\
\text { q2 weekly }\end{array}$ & $\begin{array}{l}\text { Analysis (IFL vs. } \\
\text { IFL/B): } \\
\text { - } \quad \text { RR: } 34.8 \% \text { vs. } \\
44.8 \%\end{array}$ & $\begin{array}{l}\text { Analysis (IFL vs. } \\
\text { IFL/B): } \\
\text { - } \quad \text { PFS: } 6.2 \text { mths } \\
\text { vs. } 10.6 \text { mths } \\
\text { - } \quad \text { OS: } 15.6 \text { mths } \\
\text { vs. } 20.3 \text { mths }\end{array}$ \\
\hline & E3200 [58] & $\begin{array}{c}\text { 2nd line mCRCafterfailing 5-FU } \\
\text { and/or irinotecan in combination } \\
\text { with FOLFOX-4 (820 evaluable) } \\
\text { Initial enrollment (820): } \\
\text { FOLFOX-4 (291) vs. } \\
\text { FOLFOX-4/B (286) vs. B } \\
\text { (243) }\end{array}$ & $\begin{array}{l}\text { Randomized } \\
\text { multi-center } \\
\text { open-label phase } \\
\text { III trial of } 2^{\text {nd }} \text { line } \\
\text { FOLFOX +/- } \\
\text { bevacizumab } \\
\text { Primary: OS } \\
\text { Secondary: PFS, } \\
\text { RR }\end{array}$ & $\begin{array}{l}\text { FOLFOX-4 as } \\
\text { above } \\
\\
\text { Bevacizumab: } \\
\text { IV } \\
\text { bevacizumab } \\
10 \mathrm{mg} / \mathrm{m}^{2} \\
\text { q2 weekly }\end{array}$ & $\begin{array}{l}\text { Analysis (FOLFOX-4 } \\
\text { vs. FOLFOX-4/B vs. } \\
\text { B): } \\
\text { - } \quad \text { RR: } 8.6 \% \text { vs. } 22.7 \% \\
\text { vs. } 3.3 \%\end{array}$ & $\begin{array}{c}\text { Analysis } \\
\text { (FOLFOX-4 vs. } \\
\text { FOLFOX-4/B } \\
\text { vs. B): } \\
\text { - } \\
\text { PFS: } 4.7 \text { mths } \\
\text { vs. } 7.3 \text { mths vs. } \\
2.7 \text { mths } \\
\text { - OS: } 10.8 \text { mths } \\
\text { vs. } 12.9 \text { mths } \\
\text { vs. } 10.2 \text { mths }\end{array}$ \\
\hline
\end{tabular}




\section{Continued}

TML/

ML18147

[60]

Continuation bevacizumab in mCRC with switch

chemotherapy in 1st progression (819 evaluable)

Initial enrollment (819):

- Switch chemotherapy (410)

vs. switch chemotherapy + B (409)

1st line mCRC combination bevacizumab with FOLFIRI vs. FOLFOXIRI (508 evaluable)

Initial enrollment (508):

- FOLFIRI/B vs. FOLFOXIRI/B

NSABP Adjuvant bevacizumab in stage

C-08

[62]
II/III resected CRC in combination with FOLFOX-6 (2672 evaluable)

Initial enrollment (2672):

- FOLFOX-6 (1338) vs. FOLFOX-6/B (1334)

\section{Randomized \\ multi-center \\ placebo- \\ controlled $2 \times 2$ \\ trial of 1st line $130 \mathrm{mg} / \mathrm{m}^{2} \mathrm{D} 1 \bullet$ \\ FOLFOX/XELO capecitabine

$$
\mathrm{X}+/-
$$ \\ $1000 \mathrm{mg} / \mathrm{m}^{2}$ \\ bevacizumab \\ twice daily \\ D1-D15 q3 \\ Primary: PFS}

Secondary:

on-treatment

PFS, OS, RR

Bevacizuma

$$
\text { IV }
$$

bevacizumab

$$
5 \mathrm{mg} / \mathrm{m}^{2}
$$

q2 weekly (with

FOLFOX-4) or $7.5 \mathrm{mg} / \mathrm{m}^{2}$

q3 weekly (with

XELOX)

Randomized FOLFOX-4,

multi-center

XELOX,

FOLFIRI,

XELIRI as

III trial of switch above

chemotherapy

+/- bevacizumab above

$$
\text { IV }
$$

bevacizumab 5 • $\mathrm{mg} / \mathrm{m}^{2} \mathrm{q} 2$ weekly (with

Primary: OS

Secondary: PFS, FOLFOX-4/ on-treatment FOLFIRI) or

$$
\text { PFS, RR }
$$$$
7.5 \mathrm{mg} / \mathrm{m}^{2}
$$

q3 weekly (with

XELOX/

XELIRI)

Randomized

multi-center

FOLFIRI/B as above.

III trial of

OLFOXIRI/

FOLFIRI/B vs.

FOLFOXIRI/B

B: IV

oxaliplatin

$85 \mathrm{mg} / \mathrm{m}^{2} \mathrm{D} 1$,

IV irinotecan

Primary: PFS

$165 \mathrm{mg} / \mathrm{m}^{2} \mathrm{D} 1$,

IV leucovorin,

Secondary: OS,

IV 5-FU $\mathrm{RR}, \mathrm{R} 0$ resection
rate

$48 \mathrm{hr}$ infusion

Bevacizumab: IV

bevacizumab 5

$$
\mathrm{mg} / \mathrm{m}^{2}
$$

q2 weekly

Randomized

FOLFOX-6 as

multi-center

above for 6

open-label phase

months

III trial of

FOLFOX-6 vs. Bevacizumab

FOLFOX-6/B in as above for 1

resected stage year

II/III CRC

Primary: DFS

Secondary: OS
Analysis (switch

chemotherapy vs.

switch

chemotherapy+B):

Analysis Analysis

(FOLFOX-4/

XELOX vs.

FOLFOX-4/

Investigator-assesse $\mathrm{XELOX}+\mathrm{B}$ ):

d RR: $49 \%$ vs. $47 \%$ • PFS: 8.0 mths

- Independent

response review $\bullet \quad$ On-treatment

committee RR: $38 \% \quad$ PFS: 7.9 mths vs. $38 \%$ vs 10.4 mths

- OS: 19.9 mths vs. $21.3 \mathrm{mths}$

Analysis (switch chemotherapy vs. switch

chemotherapy+B):

- On-treatment

PFS: 4.0 vs. 5.7 mths

vs. $5.4 \%$

$\begin{array}{cc}\text { DCR (SD/PR/CD): } & \bullet \quad \text { OS: } 9.8 \text { mths } \\ 54.2 \% \text { vs. } 68.1 \% & \text { vs. } 11.2 \text { mths }\end{array}$

- Median OS

from start of 1 st

line therapy:

$22 \cdot 5$ mths vs.

23.9 mths

$\begin{array}{lc}\text { Analysis (FOLFIRI/B } & \text { Analysis } \\ \text { vs. FOLFOXIRI/B): } & \text { (FOLFIRI/B vs. }\end{array}$

$\begin{array}{ll}\text { vs. FOLFOXIRI/B): } & \text { (FOLFIRI/B Vs. } \\ \text { - } \quad \text { RR (PR/CR): 53\% } & \text { FOLFOXIRI/B): }\end{array}$

Vs. $65 \%$ - Median PFS:

9.7 mths vs.

12.2 mths

- Median OS:

25.8 mths vs.

31.0 mths

- R0 resection rate: $12 \%$ vs. $15 \%$

Analysis

(FOLFOX-6 vs.

FOLFOX-6/B):

- Median DFS: HR 0.89 (nonsignificant)

- 3-year DFS: $75.5 \%$ vs. $77.4 \%$

- 3-year DFS (stage II): $84.7 \%$ vs. $87.4 \%$

- 3-year DFS (stage III): $72.4 \%$ vs. 


\section{Continued}

FIRE-3

[31]

AVAGAST

[64]

$\underset{[65]}{\operatorname{AVATAR}}$ ]

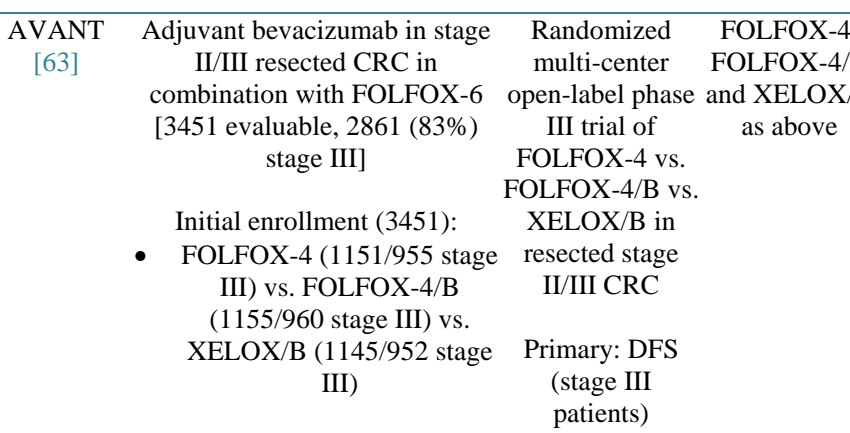

metastaticgastriccarcinoma

in combination with

cisplatin/capecitabine (774 evaluable)

Initial enrollment (774):

- CX (387) vs. CX/B (387) 1st line
metastaticgastriccarcinoma
in combination with
cisplatin/capecitabine in Asian patients (202 evaluable)

Initial enrollment (202):

- $\quad$ CX (102) vs. CX/B (100) 80303 [66] metastaticpancreaticcarcinoma in
combination with gemcitabine (535 evaluable)

Initial enrollment (535):

- $\mathrm{G}$ (256) vs. G/B (279)

$$
\begin{array}{cc}
\text { Randomized } & \text { Cisplatin/ } \\
\text { international } & \text { capecitabine } \\
\text { multi-center } & \text { (CX) as above } \\
\text { placebo- } & \\
\text { controlled phase } & \text { Bevacizumab: } \\
\text { III trial of } & \text { IV } \\
\text { cisplatin/ } & \text { bevacizumab } \\
\text { capecitabine } & 7.5 \mathrm{mg} / \mathrm{m}^{2} \\
\text { (CX) }+/- & \text { q3 weekly }
\end{array}
$$

bevacizumab

Primary: OS

Secondary: PFS,

RR

Randomized

multi-center

placebo-

controlled

phase III trial of cisplatin/

capecitabine

(CX) +/-

bevacizumab

Cisplatin/ capecitabine

as above

Bevacizumab as above

Primary: OS

Secondary: PFS, RR

Randomized multi-center placebocontrolled phase III trial of gemcitabine (G) +/- bevacizumab

Primary: OS

$$
\begin{gathered}
\text { Bevacizumab: } \\
\text { IV }
\end{gathered}
$$

Secondary: PFS, $10 \mathrm{mg} / \mathrm{m}^{2} \mathrm{D} 1$

$$
\text { RR }
$$$$
\text { bevacizumab }
$$

vs. CX/B):

IV gemcitabine

$1000 \mathrm{mg} / \mathrm{m}^{2}$

D1, 8 and 15

q4weekly

and 15

q4weekly
Not applicable $\mathrm{CX} / \mathrm{B})$ :

- RR: $37.4 \%$ vs. $46.0 \%$ (significant)

\author{
Analysis: \\ - DFS: HR 1.17 \\ (FOLFOX-4 \\ vs. \\ FOLFOX-4/B) \\ (non- \\ significant) \\ - DFS: HR 1.07 \\ (FOLFOX-4 \\ vs. XELOX/B) \\ (non- \\ significant) \\ - $\quad$ OS: HR 1.27 \\ (FOLFOX-4 \\ vs. \\ FOLFOX-4/B) \\ (significant) \\ - OS: HR 1.15 \\ (FOLFOX-4 \\ vs. XELOX/B) \\ (non- \\ significant)
}

$$
\text { sigificant) }
$$

Analysis (CX vs. $\mathrm{CX} / \mathrm{B})$ :

- Median PFS:

5.3 mths vs 6.7 mths

(significant)

- Median OS:

10.1 mths vs.

12.1 mths (nonsignificant)
Analysis (CX vs. $\quad$ Analysis (CX vs.
$\mathrm{CX} / \mathrm{B})$ :
$\mathrm{CX} / \mathrm{B})$ :
- RR (PR/CR): $33.7 \%$ - Median PFS:
vs. $40.7 \%$
DCR (PR/CR/SD):
$72.1 \%$ vs. $75.3 \%$
6.0 mths vs 6.3 mths
Median OS:
11.4 mths vs. 10.5 mths




\section{Continued}

\begin{tabular}{|c|c|c|c|c|c|c|}
\hline $\begin{array}{c}\text { Ramucirumab } \\
\text { (Cyramza }^{\circledR}, \text { Eli } \\
\text { Lilly) }\end{array}$ & $\begin{array}{l}\text { REGARD } \\
\text { (I4T-IE- } \\
\text { JVBD) [67] }\end{array}$ & $\begin{array}{l}\text { 2nd line relapsed/ } \\
\text { refractorymetastaticesopha } \\
\text { gogastriccarcinoma against BSC } \\
\text { (355 evaluable) } \\
\text { Initial enrollment (535): } \\
\text { - } \quad \text { BSC (117) vs. BSC/R (238) }\end{array}$ & $\begin{array}{l}\text { Randomized } \\
\text { international } \\
\text { placebo- } \\
\text { controlled } \\
\text { phase III trial } \\
\text { of BSC +/ } \\
\text { ramucirumab } \\
\text { Primary: OS } \\
\text { Secondary: PFS, } \\
\text { 12-week, RR }\end{array}$ & $\begin{array}{c}\text { Ramucirumab: } \\
\text { IV } \\
\text { ramucirumab } \\
8 \mathrm{mg} / \mathrm{kg} \\
\text { q2 weekly }\end{array}$ & $\begin{array}{l}\text { Analysis (BSC vs. } \\
\text { BSC/R): } \\
\text { - } \quad \text { RR (PR/CR): } 3 \% \text { vs } \\
3 \% \\
\text { - } \quad \text { DCR (PR/CR/SD): } \\
23 \% \text { vs. } 49 \%\end{array}$ & $\begin{array}{c}\text { Analysis (BSC vs. } \\
\text { BSC/R): } \\
\text { Median OS: } 3.8 \\
\text { mths vs. } 5.2 \\
\text { mths } \\
\text { - } 6 \text { month OS } \\
31.6 \% \text { vs. } \\
41.8 \% \\
12 \text { month OS } \\
11.8 \% \text { vs. } \\
17.6 \% \\
\text { Median PFS } \\
1.3 \text { mths vs. } 2.1 \\
\text { mths } \\
\text { Median } \\
12-\text { week PFS } \\
15.8 \% \text { vs. } \\
40.1 \%\end{array}$ \\
\hline & $\begin{array}{l}\text { RAINBOW } \\
\text { (I4T-IE- } \\
\text { JVBE) [68] }\end{array}$ & $\begin{array}{c}2^{\text {nd }} \text { line } \\
\text { metastaticesophagogastriccarcin } \\
\text { oma } \\
\text { in combination with paclitaxel } \\
\text { following progression on 1st line } \\
\text { platinum- and } \\
\text { fluoropyrimidine-containingche } \\
\text { motherapy (665 evaluable) } \\
\text { Initial enrollment (665): } \\
\text { • Paclitaxel (335) vs. } \\
\text { paclitaxel/R (330) }\end{array}$ & $\begin{array}{l}\text { Randomized } \\
\text { international } \\
\text { placebo- } \\
\text { controlled phase } \\
\text { III trial of } \\
\text { paclitaxel +/- } \\
\text { ramucirumab } \\
\text { Primary: OS } \\
\text { Secondary: PFS, } \\
\text { 12-week, RR }\end{array}$ & $\begin{array}{l}\text { Paclitaxel: IV } \\
\text { paclitaxel } \\
80 \mathrm{mg} / \mathrm{m}^{2} \mathrm{D} 1, \\
8,15 \text { q4 weekly } \\
\text { Ramucirumab } \\
\text { as above }\end{array}$ & $\begin{array}{l}\text { Analysis (P vs. P/R): } \\
\text { - } \quad \text { RR: } 16 \% \text { vs. } 28 \%\end{array}$ & $\begin{array}{l}\text { Analysis (P vs. } \\
\text { P/R): } \\
\text { - } \quad \text { Median OS: } 7.4 \\
\text { mths vs. } 9.6 \\
\text { mths } \\
\text { - } \quad \text { Median PFS: } \\
2.9 \text { mths vs. } 4.4 \\
\text { mths }\end{array}$ \\
\hline $\begin{array}{l}\text { Ziv-aflibercept } \\
\text { (Zaltrap }{ }^{\circledR} \text {, } \\
\text { Regeneron and } \\
\text { Bayer) }\end{array}$ & $\begin{array}{c}\text { VELOUR } \\
\text { [69] }\end{array}$ & $\begin{array}{c}\text { 2nd line mCRC in } \\
\text { combinationwith FOLFIRI } \\
\text { following priortreatment with } \\
\text { oxaliplatin-basedregimens (1226 } \\
\text { evaluable) } \\
\text { Initial enrollment (1226): } \\
\text { FOLFIRI/placebo (614) vs. } \\
\text { FOLFIRI/Z (612) }\end{array}$ & $\begin{array}{l}\text { Randomized } \\
\text { multi-center } \\
\text { placebo- } \\
\text { controlled phase } \\
\text { III trial of } \\
\text { FOLFIRI/ } \\
\text { placebo vs. } \\
\text { FOLFIRI/Z } \\
\text { Primary: OS } \\
\text { Secondary: RR }\end{array}$ & $\begin{array}{l}\text { FOLFIRI as } \\
\text { above } \\
\text { q2 weekly } \\
\text { Aflibercept: IV } \\
\text { aflibercept } 4 \\
\text { mg/kg q2 } \\
\text { weekly }\end{array}$ & $\begin{array}{c}\text { Analysis } \\
\text { (FOLFIRI/placebo vs. } \\
\text { FOLFIRI/Z): } \\
\text { - } \text { RR (PR/CR): } 11.1 \% \\
\text { vs } 19.8 \%\end{array}$ & $\begin{array}{c}\text { Analysis } \\
\text { (FOLFIRI/placebo } \\
\text { vs. FOLFIRI/Z): } \\
\text { - Median OS: } \\
12.1 \text { mths vs. } \\
13.5 \text { mths } \\
\text { - } \quad 2 \text { year survival: } \\
18.7 \% \text { vs. } \\
28.0 \% \\
\text { Median PFS: } \\
4.7 \text { mths vs. } 6.9 \\
\text { mths }\end{array}$ \\
\hline & $\begin{array}{c}\text { VANILLA } \\
{[70]}\end{array}$ & $\begin{array}{c}\text { 1st line } \\
\text { metastaticpancreaticcarcinoma in } \\
\text { combination with gemcitabine } \\
\text { (546 evaluable) } \\
\text { Initial enrollment (546): } \\
\text { - G/placebo (275) vs. G/Z } \\
\text { (271) }\end{array}$ & $\begin{array}{l}\text { Randomized } \\
\text { multi-center } \\
\text { placebo- } \\
\text { controlled } \\
\text { phase III trial of } \\
\text { G/placebo vs. } \\
\text { G/Z } \\
\text { Primary: OS } \\
\text { Secondary: PFS, } \\
\text { RR }\end{array}$ & $\begin{array}{c}\text { Gemcitabine: } \\
\text { IV gemcitabine } \\
1000 \mathrm{mg} / \mathrm{m}^{2} \\
\text { qweekly for } 7 \\
\text { weeks out of } 8 \\
\text { then qweekly } \\
\text { for } 3 \text { weeks out } \\
\text { of } 4 \\
\text { Aflibercept as } \\
\text { above }\end{array}$ & $\begin{array}{l}\text { Analysis (G/placebo vs. } \\
\text { G/Z): } \\
\text { RR (PR/CR): Not } \\
\text { reported } \\
\end{array}$ & $\begin{array}{c}\text { Analysis } \\
\text { (G/placebo vs. } \\
\text { G/Z): } \\
\text { - } \quad \text { Median OS: } 7.8 \\
\text { mths vs. } 6.5 \\
\text { mths } \\
\text { - } 6 \text { mth survival: } \\
63 \% \text { vs } 54 \% \\
\text { - } 12 \text { mth } \\
\text { survival: } 25 \% \\
\text { vs. } 21 \% \\
\text { Median PFS: } \\
3.7 \text { mths vs. } 3.7 \\
\text { mths } \\
6 \text { mth PFS: } \\
30 \% \text { vs. } 27 \% \\
12 \text { mth PFS: } \\
4 \% \text { vs. } 3 \%\end{array}$ \\
\hline
\end{tabular}




\begin{tabular}{|c|c|c|c|c|c|}
\hline \multicolumn{6}{|l|}{ Continued } \\
\hline $\begin{array}{l}\text { Trastuzumab } \\
\text { (Herceptin }^{\circledR}, \\
\text { Roche) }\end{array}$ & $\begin{array}{l}\text { 1st line metastatic HER2+ } \\
\text { GEJ/gastriccarcinoma in } \\
\text { combination with cisplatin and } \\
\text { 5-FU/capecitabine (CF or CX) } \\
\text { (584 evaluable) } \\
\text { Initial enrollment (584): } \\
\text { Chemotherapy (290) vs. } \\
\text { chemotherapy/T (294) }\end{array}$ & $\begin{array}{c}\text { Randomized } \\
\text { international } \\
\text { multi-center } \\
\text { open-label phase } \\
\text { III trial of } \\
\text { chemotherapy vs. } \\
\text { chemotherapy/T } \\
\text { Primary: OS } \\
\text { Secondary: PFS, } \\
\text { RR }\end{array}$ & $\begin{array}{l}\text { Chemotherapy } \\
\text { (CF/CX): } \\
\text { Cisplatin/5-FU } \\
\text { (CF): IV } \\
\text { cisplatin } \\
80 \mathrm{mg} / \mathrm{m}^{2} \mathrm{D} 1+ \\
\text { IV 5-FU } \\
800 \mathrm{mg} / \mathrm{m}^{2} \\
\text { daily D1-5 } \\
\text { Cisplatin/ } \\
\text { capecitabine } \\
\text { (CX) as above } \\
\\
\text { Trastuzumab: } \\
\text { IV trastuzumab } \\
8 \text { mg/kg } \\
\text { induction } \\
\text { followed } \\
\text { by maintenance } \\
\text { IV trastuzumab } \\
6 \text { mg/kg } \\
\text { q3 weekly }\end{array}$ & $\begin{array}{l}\text { Analysis (chemotherapy } \\
\text { vs. chemotherapy/T): } \\
\text { - RR (PR/CR): } 35 \% \\
\text { vs } 47 \% \\
\text { DCR (PR/CR/SD): } \\
70 \% \text { vs. } 79 \% \\
\end{array}$ & $\begin{array}{c}\text { Analysis } \\
\text { (chemotherapy vs. } \\
\text { chemotherapy/T): } \\
\text { - } \quad \text { Median OS: } \\
11.1 \text { mths vs. } \\
13.8 \text { mths } \\
\text { - } \quad \text { Median PFS: } \\
5.5 \text { mths vs. } 6.7 \\
\text { mths }\end{array}$ \\
\hline
\end{tabular}

PFS—progression-free survival; OS—overall survival; mCRC—-metastatic colorectal carcinoma; BSC—best supportive care; RR—response rate; DCR - disease control rate.

However, a recent phase II study reported OS results that would be inferior when compared to sorafenib [53]. No further phase III evaluation of EGFR inhibition is planned in this disease.

\subsection{VEGF Inhibition: Bevacizumab (Avastin ${ }^{\circledR}$ ), Ramucirumab (Cyramza ${ }^{\circledR}$ ) and Ziv-Aflibercept (Zaltrap ${ }^{\circledR}$ )}

The ability of tumors to induce angiogenesis is a central concept in cancer proliferation [54]. Our understanding of tumor angiogenesis and its inhibition has evolved considerably: rather than directly inhibit tumor growth, VEGF-inhibition may mainly normalize abnormal tumor vasculature and improve delivery of cytotoxic agents [55].

Bevacizumab is a humanized monoclonal antibody that binds circulating VEGF-A, preventing its engagement with downstream VEGF receptors (VEGFR-1/2/3) with multifarious effects including inhibition of angiogenic signaling. Bevacizumab was the first biologic agent approved by the FDA to treat any malignancy in 2004 and EMA approval followed in 2005. Approval centered on the results of a front-line randomized phase III study in metastatic CRC with the combination of cytotoxic IFL (irinotecan/5-FU/leucovorin) chemotherapy plus bevacizumab vs. placebo, in which bevacizumab conferred an OS benefit of 4.7 months over IFL alone (20.3 vs. 15.6 months) [56]. A flurry of trials followed, evaluating bevacizumab's role in 1st and 2nd line settings with alternative chemotherapy combinations and in other diseases (non-small cell lung cancer, renal cell carcinoma, ovarian carcinoma, and glioblastomamultiforme). These results are summarized in Table 2 [56]-[69].

The aggregate data demonstrated that bevacizumab is preferred in KRAS mutant mCRCpatients population since they do not benefit from EGFR inhibition. Mounting evidence supports prolonged duration of anti-VEGF therapy in metastatic CRC. NO16966 data suggested further improvement when bevacizumab was continued till overt progression and ML18147 confirmed that bevacizumab continuation past progression improved PFS and OS [59] [60]. Based on the negative results of AVANT and NSABP C-08, bevacizumabdid not show obvious benefit in either overall survival (OS) or disease-free survival(DFS) at the adjuvant setting for resected CRC [62] [63].

The role of bevacizumab in gastroesophageal cancer treatment has not been approved based on the 2 published large randomized phase III studies (AVAGAST, AVATAR). The AVAGAST study compared chemotherapy versus chemotherapy plus bevacizumab as the first line in patients with metastatic gastric cancer. Although, the study did not show obvious survival benefit by adding bevacizumab, patients with high baseline plasma VEGF-A levels, and low baseline expression of neuropilin-1 showed a trend toward improved overall survival [64] [106]. The other study, AVATAR, did not show benefit of bevacizumabadding to the combination of capecitabine and cisplatin in Chinese patients with metastatic gastric cancer [65]. A randomized phase III 
study (ST03) is evaluating the role of adjuvant VEGF inhibition in EGJ/proximal gastric adenocarcinomas.

Ramucirumab is a fully human monoclonal antibody (IgG1) asVEGFR2 receptor antagonist that prevents the binding of VEGF to VEGFR2 - the interaction thought to mediate the bulk of VEGF downstream effects. Ramucirumabmonotherapy modestly improved OS (5.2 months vs. 3.8 months) in 2nd line advanced EGJ/gastric carcinoma compared to placebo after prior platinum-containing or fluoropyrimidine-containing chemotherapy [67]. Ramucirumab has demonstrated benefit in the $2^{\text {nd }}$ line setting when combined with paclitaxel chemotherapy in patients who progressed on prior $1^{\text {st }}$ line platinum- and 5-FU-based combinations (RAINBOW) [68]. The median overall survival was 9.6 months for the ramucirumab and paclitaxel combination compared to 7.4 months for paclitaxel alone $(\mathrm{p}=0.0169)$ with $19 \%$ reduction in the risk of death. Prior front-line studies utilizing bevacizumab (AVAGAST, AVATAR) were negative, and it is possible that the benefit seen with ramucirumab is secondary to the greater interruption of VEGF signaling with ramucirumabcompared to bevacizumab [64] [65].

For unclear reason, VEGF inhibition has not proved beneficial in pancreatic carcinoma (CALGB 80303-bevacizumab, VANILLA-aflibercept) [66] [70].

In contrast to bevacizumab and ramucirumab, ziv-aflibercept (Zaltrap ${ }^{\circledR}$ ) is a fusion protein that acts as a decoy receptor for VEGF-A, VEGF-B, and placental growth factor (PIGF). In vitro studies demonstrated that zivaflibercept bound VEGF-A with 100-fold greater affinity and more potent blockade of VEGFR-1/VEGFR-2 than bevacizumab. The phase III VELOUR trial evaluated the combination of ziv-aflibercept and FOLFIRI in the second line metastatic CRC after progression on prior oxaliplatin-based therapy and reported modest benefit [69]. Data to support the use of ziv-aflibercept in the $1^{\text {st }}$ line setting is lacking-the AFFIRM trial which reported similar PFS between both arms was a non-comparative study that was not powered to evaluate the addition of ziv-aflibercept to FOLFOX-6 compared to FOLFOX-6; hence the trial is better considered as an evaluation of alternative $1^{\text {st }}$ line VEGF inhibition together with FOLFOX-6 [71] [72]. A phase II trial is evaluating the OPTIMOX strategy (FOLFOX-7) in the $1^{\text {st }}$ line setting in combination with aflibercept (NCT01802684, VELVET).

In HCC, bevacizumab has shownimproved survival singly and in combination in multiple phase II studies. VEGF inhibition is considered to have a role in the systemic treatment of advanced HCC in addition tosorafenib [73] [74]. However, further randomized phase III trials are needed to confirm this result.

\subsection{Monoclonal Antibodies: Her-2/neu Inhibition: Trastuzumab (Herceptin ${ }^{\circledR}$ ), Pertuzumab (Perjeta ${ }^{\circledR}$ ) and Trastuzumab-Emtansine (T-DM1, Kadcyla ${ }^{\circledR}$ )}

HER2/neu encodes the ERBB2 protein, a member of the EGFR family of receptor tyrosine kinases-all of which comprise an extracellular ligand binding domain, a transmembrane domain, and an intracellular domain. HER2 ligand binding activates multiple downstream signals including via the MAPK (RAS/RAF/MEK/ERK), PI3K/AKT, STAT, phospholipase $\mathrm{C} \gamma$ and protein kinase $\mathrm{C}$ pathways. HER2/neu over expression has been observed in approximately $15 \%$ - $25 \%$ of breast cancers and is associated with poorer responses to therapy and a clinically aggressive course. HER2/neu over expression occurs at a slightly lower frequency $(12 \%-22 \%)$ in esophagogastric malignancies compared to breast cancers although the prognostic implication is unclear [75][77]. Incidence between esophageal and gastric malignancies is similar; though among gastric cancer sub-types, HER2/neu positivity is seen more often with intestinal-type than diffuse-type cancers [78]. For the $7 \%$ - $22 \%$ of patients whose tumors overexpress HER2 by FISH or IHC, the phase III TOGA study was unequivocally positive and resulted in regulatory approval for 1st line use (see Table 2) [79]. TOGA's chemotherapy arm consisted of cisplatin with 5-FU or capecitabine, and the addition of trastuzumab to regimens.

Diminished efficacy to trastuzumab may develop secondary to primary or secondary resistance-with primary resistance rates as high as $66 \%$ - $88 \%$ in HER2-overexpressing metastatic breast cancer. Although several mechanisms of resistance in breast cancer have been proposed, no data is available in EGJ/gastric carcinomas. Pharmacokinetic data from phase I/II breast cancer trials suggests that failure to achieve steady-state levels secondary to rapid clearance may contribute to primary resistance [80]. HELOISE (NCT01450696) is an international phase III study (NCT01450696) evaluating standard $(8 \mathrm{mg} / \mathrm{kg}$ loading, then $6 \mathrm{mg} / \mathrm{kg}$ q3 weekly) versus high (8 mg/kg loading, then $10 \mathrm{mg} / \mathrm{kg} \mathrm{q}^{3}$ weekly) in advanced HER2+ EGJ/gastric carcinomas.

Trastuzumabemtansine (T-DM1) is an antibody-drug conjugate consisting of trastuzumab linked to the antitubulin agent mertansine (DM1). T-DM1 improved survival by 5.8 months compared to lapatinib/capecitabine in trastuzumab resistant metastatic breast cancer [81]. In advanced HER2+ EGJ/gastric carcinomas, T-DM1 is 
being evaluated in combination with physician choice taxane (docetaxel or paclitaxel). The phase II/III study (NCT01641939) utilizes a novel adaptive design that will evaluate two schedules of T-DM1 (2.4 or $3.6 \mathrm{mg} / \mathrm{kg}$ q3 weekly) and pick the phase III dose of T-DM1 depending on the tolerability at 12 weeks. Pertuzumab is a humanized monoclonal antibody that inhibits HER2 dimerization, as distinct from trastuzumab. Combined HER2 blockade with trastuzumab/pertuzumab was evaluated in both the neoadjuvant (TRYPHAENA) and metastatic settings (CLEOPATRA) in breast cancer with high pathologic complete response (pCR) rates and significant improvements in OS respectively [82] [83]. Combined HER2 blockade in HER2+ EGJ/gastric carcinomas with trastuzumab/pertuzumab is under evaluation in a phase III trial (BO25114, NCT01774786).

HER2 inhibition is not being evaluated in other GI malignancies.

\subsection{Checkpoint Inhibitors: Cytotoxic T Lymphocyte Antigen-4 (CTLA-4) and Programmed Death-1 (PD-1)}

Peptide antigens presented in association with major histocompatibility proteins (MHC) by antigen-presenting cells (APC) to T-cell receptors (TCR) triggers antigen-specific T-cell activation. T-cells have evolved a two-step mechanism that requires a second signal to mediate whether the antigen-TCR interaction results in proliferation, cytokine secretion, and differentiation or development of tolerance and anergy. T-cell co-stimulatory and co-inhibitory signals are thus potent homeostatic mechanisms that maintain a balance between effective immune responses and peripheral tolerance. T-cell CD28 is the primary co-stimulatory signal modulator while CTLA-4 (CD152) is the primary co-inhibitory signal regulator for CD4+ T-helper, CD8+ T-effector and CD25+ Foxp3+ regulatory $\mathrm{T}$ cells. The functional outcome of the ligand-APC-T-cell interaction depends on the relative engagement between APC B7-1/B7-2 (CD80/86) and T-cell CD28 versus CTLA-4.

In addition to CTLA-4, several T-cell surface molecules participate in negative and positive regulation of T-cell activation. The exact role of these molecules in T-cell priming, growth and survival and more specifically in T-effector function, T-helper differentiation, and memory T-cell sustenance are reviewed elsewhere [84]. While CTLA-4 initiates the negative feedback loop in T-cell activation, PD-1 is part of the effector phase of this loop. PD-L1 is ubiquitously expressed on tumors and the PD-1/PD-L1 interaction downregulates T-effector responses possibly through suppression of PI3K/AKT activation [85].

CTLA-4 blockade and PD-1 inhibition were thus attractive targets to augment anti-tumor T-cell immunity in cancer. Two CTLA-4 inhibitors [ipilimumab (Yervoy, BMS) and tremelimumab (CP-675206)] and several PD-1/PD-L1 inhibitors have been developed [nivolumab (BMS-936558, BMS), lambrolizumab (MK-3475, Merck) and MPDL3280A (Roche/Genentech/Chugai)] and are in various phases of clinical testing. Of these, ipilimumab has been approved for the treatment of metastatic melanoma in both the 1st line and relapsed settings following successful phase III trials against chemotherapy (dacarbazine) and vaccine (GP-100) comparators respectively [86] [87]. Despite promising phase II results, a phase III study of tremelimumab in advanced melanoma was negative and further interest has stalled [88].

Initial evaluation of PD-1 and CTLA-4 inhibition in GI malignancies centered on pancreatic carcinoma but was subsequently extended to advanced CRC and HCC [89]. Microsatellite stability is an important prognostic marker in CRC: tumors with high-degree microsatellite instability (MSI-H) have a better prognosis than tumors with low-degree instability (MSI-L) or stable microsatellite (MSS) status. This may be related, in part, to greater immunogenicity associated with MSI-H tumors [90] [91]. Investigational approaches in advanced MSI-H CRC include PD-1 (NCT01876511) or PD-1/CTLA-4 combination (NCT01928394, CheckMate 142). Early phase studies are evaluating this approach in combination with chemotherapy in advanced pancreatic cancer (NCT01473940-gemcitabine/ipilimumab and NCT01896869-FOLFIRINOX/GM-CSF vaccine) and singly in advanced HCC (NCT01658878). A summary of the ongoing trials is provided in Table 3.

\subsection{Vaccines}

Cancer vaccines aim to produce persistent anti-tumor immunity that result in prolonged durable responses. Vaccines are classified based on the antigen(s) incorporated - whole cell, protein, peptide, recombinant virus, dendritic cell, and naked DNA. Cancer vaccines have been studied in various settings (adjuvant, neo-adjuvant and metastatic) across a gamut of malignancies. It is beyond the scope of the article to discuss these studies in detail; however the NCI experience with cancer vaccination between 1995 and 2010 was reviewed in 2 separate publi- 
Table 3. Phase I/II trials of co-stimulatory agents in GI malignancies in accrual.

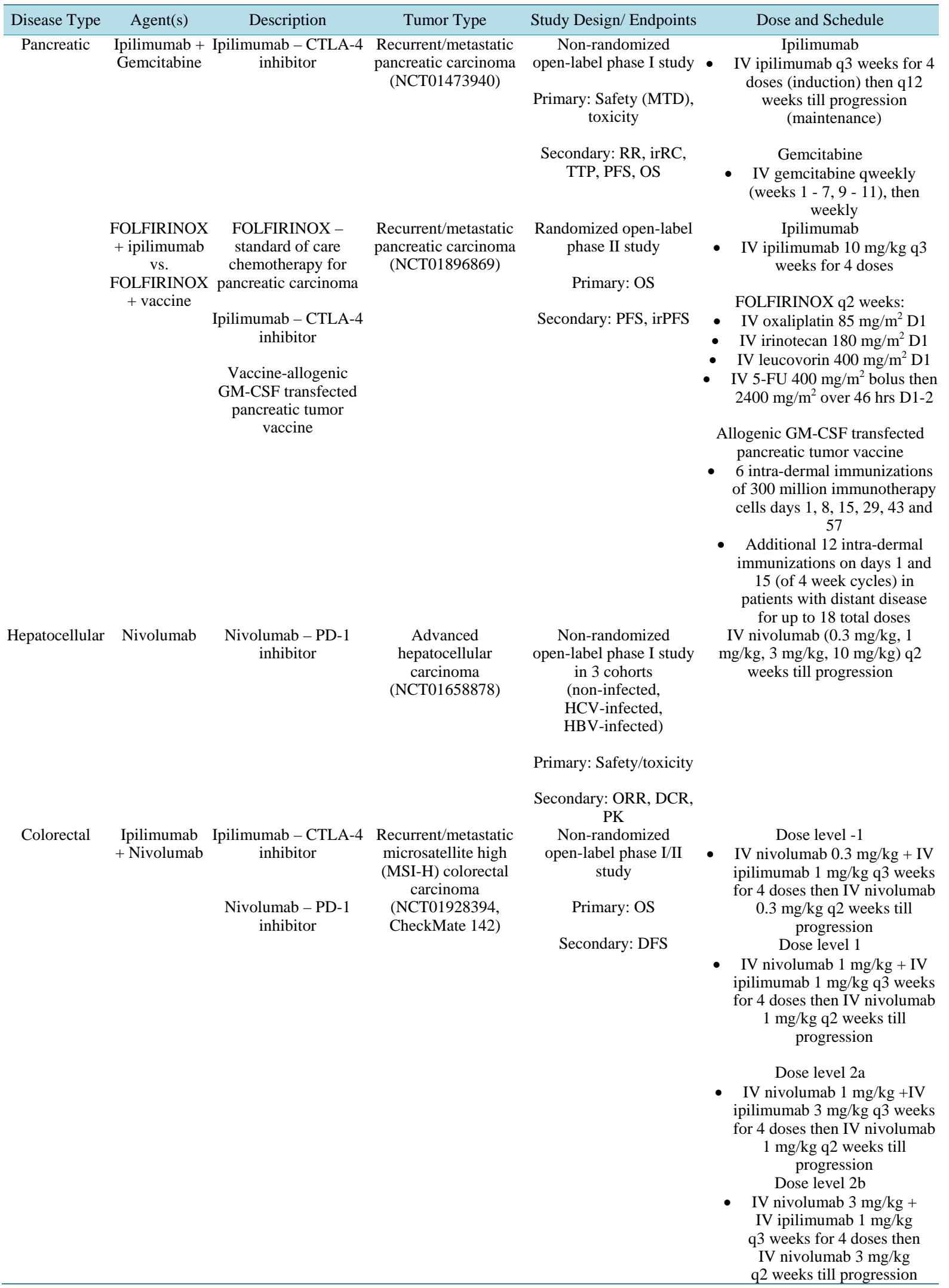


Continued

$\begin{array}{ccccc}\text { MK-3475 } & \begin{array}{c}\text { MK-3475 - PD-1 } \\ \text { inhibitor }\end{array} & \begin{array}{c}\text { Recurrent/metastatic } \\ \text { colorectal carcinoma } \\ \end{array} & \begin{array}{c}\text { Non-randomized } \\ \text { (MSI and MSS) and }\end{array} & \text { open-label phase II study } \\ & \text { non-colorectal MSI } & \text { Primary: 20-week irPFS, } \\ & \text { tumors(NCT01876511) } & \text { 20-week irOR } & \text { MK-345 10 mg/kg q2 } \\ & & & \text { weeks till progression } \\ & & & \end{array}$

Secondary: OS, RR, DCR

MTD—maximal tolerated dose; RR—response rate; irOR—immune-related objective response; irRC—immune-related response criteria; TTP—-time to progression; PFS—-progression-free survival; irPFS—immune-related progression-free survival; OS—overall survival.

cations and reported low response rates of 3\% - 4\% with only infrequent CRs in select malignancies [92] [93].

As TAA have been identified in esophageal (MAGE-A3/4 and NYESO-1), gastric (Her-2/neu), pancreatic (MUC1 and mesothelin), hepatocellular (AFP, GPC3, NY-ESO-1, SSX-2, MAGE-A and TERT) and colorectal (CEA) malignancies, cancer vaccination is an attractive strategy in GI malignancies. Given the lack of proven benefit in the phase III setting, no cancer vaccine is approved in the adjuvant, neo-adjuvant and/or advanced disease settings so far. The panoply of ongoing vaccine trials in GI malignancies is summarized in Table 4.

Several early phase vaccine studies in CRC and esophagogastric cancers are in accrual.

- Adjuvant CRC: phase I study of engineered alphavirus vaccine expressing CEA in stage III disease (NCT01890213).

- Advanced CRC: colorectal GVAX (in combination with Cy + DNA methyltransferase inhibitor SGI-110, NCT01309126); DC vaccination (NCT01348256); and polysaccharide beta 1,3/1,6 glucan(Imprime PGG) with cetuximab compared to cetuximab alone in KRAS WT patients at 1st progression (PRIMUS, NCT01309126).

- Adjuvant esophagogastric cancers following definitive surgery and combined modality therapy: NY-ESO-1 expressing tumors (NCT01522820); cancer testis antigen expressing tumors (NCT01143545 and NCT02054104).

- Advanced gastric cancer: HER2 positive (AVX901-NCT01526473); and FOXM1/DEPDC1/KIF20A/ URLC10/VEGFR1 positive in patients withwith HLA-2402 haplotype (OTSGC-A24-NCT01227772).

In advanced pancreatic cancer, several adjuvant vaccines have been developed including whole cell vaccines (Algenpantucel-L, GM-CSF vaccine); peptide and DNA vaccines [Ras, telomerase peptide, survivin, oncofetal peptides CEA/MUC1]; DC vaccines (utilizing CEA/MUC1 antigen pulsed DC cells) and heat-shock protein (HSP). Aside from Algenpantucel-L (HyperAcute ${ }^{\circledR}$, NewLink Genetics Corporation) and GVAX, these approaches have largely been unsuccessful and are reviewed elsewhere [94].

Algenpantucel-L is an allogeneic whole pancreatic cell vaccine engineered to express $\alpha$-galactosyl ( $\alpha \mathrm{Gal})$ epitopes that elicit complement-mediated lysis and antibody-dependent cell-mediated toxicity. GVAX is a tumor cell vaccine created by harvesting allogenic cancer cells with subsequent transfection of the granulocyte macrophage-colony stimulating factor (GM-CSF) gene. The algenpantucel-L phase II study involved 70 patients with resected pancreatic adenocarcinoma who received algenpantucel-L vaccination in addition to 5-FU/gemcitabine based chemoradiotherapy (investigational arm of RTOG-9704) post-operatively. Allowing for inherent biases in cross-trial comparisons, 12-month DFS and OS were improved with the addition of algenpantucel-L compared to 5-FU/gemcitabine chemoradiotherapy arm in RTOG-9704 [95] [96]. Algenpantucel-L is pending evaluation in a phase III study comparing 5-FU/gemcitabine chemoradiotherapy with or without algenpantucel-L immunization in resected high-risk pancreatic carcinoma (NCT01072981).

Early studies of GVAX immunotherapy in renal cell cancer and melanoma produced middling results but the approach gained traction when an early study reported durable long-term responses in patients with advanced non-small cell lung cancer [97]. Both ipilimumab and GVAX have previously been evaluated in advanced pancreatic adenocarcinoma with negative results previously [98] [99]. Recent work has shed light on the extensive immunosuppressive microenvironment encircling the primary tumor in pancreatic adenocarcinoma, and explains the poor results observed with conventional immunotherapeutic approaches in prior studies [100]. Paradoxically, given the limited access to host immune cells, pancreatic cells may actually be more sensitive to immune attack; and suggests that strategies that combine vaccination with immune checkpoint blockade may be more successful than unselected vaccination. Results of a recent phase Ib study combining GVAX vaccination and ipilimumab in advanced pancreatic adenocarcinoma patients in the 2nd line setting were promising [101]. This has prompted 
Table 4. Trials of cancer vaccines in GI malignancies in accrual.

\begin{tabular}{ccc}
\hline Disease Type & $\begin{array}{c}\text { Agent (Trade } \\
\text { name, Sponsors) }\end{array}$ & Description \\
\hline $\begin{array}{c}\text { NY-ESO-1 } \\
\text { expressing } \\
\text { tumors } \\
\text { (esophageal, } \\
\text { gastric, HCC, } \\
\text { colorectal) }\end{array}$ & $\begin{array}{c}\text { ESO-1 fusion } \\
\text { protein vaccine }\end{array}$ & $\begin{array}{c}\text { mTOR inhibition with } \\
\text { rapamycin for enhancing } \\
\text { intranodal dendritic cell } \\
\text { vaccine induced anti-tumor } \\
\text { immunity in patients with } \\
\text { NY-ESO-1 expressing solid } \\
\text { tumors }\end{array}$ \\
& & $\begin{array}{c}\text { Nymor } \\
\text { Esophageal }\end{array}$ \\
& K562-GM tumor & Allogeneic K562-GM tumor \\
& cell vaccine & cell vaccine expressing cancer \\
& & testis antigens
\end{tabular}

H1299 cell lysate/Iscomatrix vaccine

Allogeneic H1299 cell lysate/Iscomatrix vaccine expressing cancer testis antigens

Gastric

AVX901

OTSGC-A24

Allogeneic cell vaccine expressing tumor specific antigensand VEGFR1

HLA-A24 epitopes
Resected high-risk thoracic malignancies (including esophageal) expressing cancer testis antigens (NCT01143545)
Resected high-risk thoracic malignancies (including esophageal) expressing cancer testis antigens (NCT02054104)

Secondary: NY-ESO-1 specific cellular and humoral immunity

Non-randomized phase I/II study of K562-GM tumor cell vaccine in combination with metronomic oral cyclophosphamide and celecoxib

$$
\text { Primary: Safety }
$$

Secondary: Induction of immunity; reduction of T-regulatory cells in peripheral blood

Randomized phase I/II study of H1299 cell lysate/Iscomatrix vaccine with or without the combination with metronomic oral cyclophosphamide and celecoxib

Primary: Immune response rates

Secondary: Immune response rates Non-randomized phase I study of AVX901 vaccine

Primary: Safety

Secondary: Induction of HER2 specific immunity

Metastatic gastric adenocarcinoma (NCT01526473)

Non-randomized phase I/IIa study of OTSGC-A24 vaccine

Primary: Safety

Secondary: Induction of T-effector specific immunity

Resected high-risk pancreatic carcinoma (NCT01072981)

Randomized open-label phase III trial of algenpantucel-L gemcitabine with or without 5-flurouracil (5FU) chemoradiation vs. gemcitabine with or without 5FU chemoradiation alone

Primary: OS

Secondary: DFS

Borderline resectable or locally Randomized open-label phase III trial of advanced unresectable pancreatic algenpantucel-L with FOLFIRINOX vs. carcinoma (NCT01836432)
FOLFIRINOX alone

Primary: OS 


\section{Continued}

\begin{tabular}{|c|c|c|c|c|}
\hline \multirow[t]{4}{*}{$\begin{array}{l}\text { Pancreatic } \\
\text { Cancer }\end{array}$} & $\begin{array}{l}\text { GVAX + } \\
\text { CRS-207 }\end{array}$ & $\begin{array}{l}\text { CRS-207-attenuated Listeria } \\
\text { monocytogenes genetically } \\
\text { engineered to elicit immune } \\
\text { responses against } \\
\text { tumor-associated mesothelin }\end{array}$ & $\begin{array}{l}\text { Relapsed/refractory pancreatic } \\
\text { carcinoma (ECLIPSE) } \\
\text { (NCT02004262) }\end{array}$ & $\begin{array}{l}\text { Randomized open-label phase IIB trial } \\
\text { of vs GVAX + CRS-207 vaccination. } \\
\text { CRS-207 vaccination alone vs. } \\
\text { chemotherapy }\end{array}$ \\
\hline & & & & Primary: OS \\
\hline & & $\begin{array}{l}\text { GVAX - tumor cell vaccine } \\
\text { created by harvesting allogenic } \\
\text { cancer cells with subsequent } \\
\text { transfection of the granulocyte } \\
\text { macrophage-colony } \\
\text { stimulating factor (GM-CSF) } \\
\text { gene. }\end{array}$ & & Secondary: toxicity \\
\hline & & $\begin{array}{l}\text { Cyclophosphamide (Cy) - } \\
\text { low-dose metronomic } \\
\text { cyclophosphamide }\end{array}$ & & \\
\hline \multirow[t]{9}{*}{$\begin{array}{l}\text { Colorectal } \\
\text { carcinoma }\end{array}$} & $\begin{array}{l}\text { GVAX + Cy + } \\
\quad \text { SGI-110 }\end{array}$ & $\begin{array}{c}\text { SGI-110 - DNA } \\
\text { methyltransferase inhibitor }\end{array}$ & $\begin{array}{l}\text { mCRC maintenance therapy } \\
\text { (NCT01309126) }\end{array}$ & $\begin{array}{l}\text { Open-label phase I trial of SGI-110 in } \\
\text { combination with GVAX/Cy as } \\
\text { maintenance therapy }\end{array}$ \\
\hline & & $\begin{array}{l}\text { GVAX - tumor cell vaccine } \\
\text { created by harvesting allogenic } \\
\text { cancer cells with subsequent }\end{array}$ & & Primary: Safety/toxicity \\
\hline & & $\begin{array}{l}\text { transfection of the granulocyte } \\
\text { macrophage-colony } \\
\text { stimulating factor (GM-CSF) } \\
\text { gene. }\end{array}$ & & Secondary: OS, PFS, TTP \\
\hline & & $\begin{array}{l}\text { Cyclophosphamide (Cy) - } \\
\text { low-dose metronomic } \\
\text { cyclophosphamide }\end{array}$ & & \\
\hline & $\begin{array}{l}\text { CEA(6D)-VRP } \\
\text { (AVX701) }\end{array}$ & $\begin{array}{l}\text { Recombinant Venezuelan } \\
\text { equine encephalitis (VEE) }\end{array}$ & $\begin{array}{l}\text { Stage III colorectal carcinoma } \\
\text { following completion of adjuvant }\end{array}$ & Open-label phase I trial of AVX701 \\
\hline & & $\begin{array}{l}\text { alphavirus packaged in } \\
\text { virus-like replicon particles }\end{array}$ & $\begin{array}{l}\text { 5-FU based chemotherapy } \\
\text { (NCT01890213) }\end{array}$ & Primary: Safety/toxicity \\
\hline & & $\begin{array}{l}\text { (VRP) expressing CEA (6D) } \\
\text { (to enhance binding to } \\
\text { HLA-A2, and enhanced } \\
\text { recognition by TCR) }\end{array}$ & & Secondary: None \\
\hline & DC vaccine & $\begin{array}{l}\text { DC vaccination with } \\
\text { autologous tumor antigen }\end{array}$ & $\begin{array}{l}\text { mCRC with hepatic metastasis } \\
\text { following resection and standard } \\
\text { adjuvant chemotherapy } \\
\text { (NCT01348256) }\end{array}$ & $\begin{array}{l}\text { Open-label phase II trial of DC } \\
\text { vaccination }\end{array}$ \\
\hline & $\begin{array}{l}\text { Imprime PGG } \\
\text { and cetuximab or } \\
\text { cetuximab alone }\end{array}$ & $\begin{array}{l}\text { Imprime PGG-polysaccharide } \\
\text { beta 1.3/1.6 glucan derived } \\
\text { from Saccharomyces cerevi } \\
\text { siae cell wall }\end{array}$ & $\begin{array}{l}\text { Recurrent/metastatic KRAS WT } \\
\text { CRC (PRIMUS) (NCT01309126) }\end{array}$ & $\begin{array}{l}\text { Randomized open-label phase III trial of } \\
\text { cetuximab vs. cetuximab/Imprimg PGG } \\
\text { Primary: OS }\end{array}$ \\
\hline \multirow[t]{4}{*}{$\begin{array}{l}\text { Hepatocellular } \\
\text { Cancer }\end{array}$} & COMBIG-DC & Intra-tumoral DC vaccine & Advanced HCC (NCT01974661) & $\begin{array}{c}\text { Secondary: RR, PFS } \\
\text { Open-label phase I trial of DC } \\
\text { vaccination }\end{array}$ \\
\hline & & & & Primary: Safety/tolerability \\
\hline & & & & Secondary: RR, tumor marker (AFP) \\
\hline & $\begin{array}{l}\text { Cytokine-induced } \\
\text { killer (CIK) cells }\end{array}$ & $\begin{array}{l}\text { Ex-vivo expanded T-cells } \\
\text { which present a mixed T/NK } \\
\text { phenotype and have } \\
\text { MHC-unrestricted antitumor } \\
\text { activity }\end{array}$ & $\begin{array}{c}\text { Hepatocellular carcinoma } \\
\text { post-resection (NCT01749865) }\end{array}$ & $\begin{array}{l}\text { Randomized open-label phase III trial of } \\
\text { standard care vs. CIK } \\
\text { Primary: Time to recurrence }\end{array}$ \\
\hline
\end{tabular}

PFS—progression-free survival; DFS—disease-free survival; OS—overall survival; TTP—-time to progression; RR—response rate. 
further investigation in the adjuvant setting with GVAX alone in combination with FOLFIRINOX, RT and low-dose cyclophosphamide (NCT01595321) and in advanced disease-GVAX/ipilimumab with FOLFIRINOX (NCT01896869), and GVAX with CRS-207 (ECLIPSE, NCT02004262).

Vaccination is also an exciting option in HCC especially considering the presence of HCC-specific TAA (AFP, GPC3, NY-ESO-1, SSX-2, MAGE-A and TERT). Although the tolerogenic tumor micro-environment and HCC-specific tumor suppressive mechanisms are considerations underlying successful vaccination, several studies have demonstrated the validity of this approach. A Japanese study of 150 patients randomized following curative resection to either observation or vaccination with autologous lymphocytes activated in vitro by IL-2 and anti-CD3 reported improved RFS and disease specific survival [102]. More recently, an autologous pulsed dendritic cell (DC) approach demonstrated clinical benefit in advanced disease [103]. Ongoing vaccine study strategies include intra-tumoral DC vaccination (NCT01974661), NY-ESO-1 vaccination in combination with sirolimus (NCT01522820) and adjuvant treatment following hepatectomy with cytokine-induced T-cells (NCT01749865).

\section{Conclusions}

With the advent of efficacious cytotoxic options in GI malignancies, immunotherapeutic approaches were not pursued aggressively. However, the development and subsequent success of VEGF, EGFR and HER2 inhibition in several GI malignancies have rekindled interest in MoAbs targeting these axes in several settings.

VEGF inhibition (bevacizumab, ziv-aflibercept and regorafenib) and EGFR inhibition (in KRAS/NRAS WT patients) have well defined roles in the management of metastatic CRC. In advanced KRAS/NRAS WT mCRC, both VEGF (bevacizumab) and EGFR (cetuximab/panitumumab) inhibition should be pursued.

EGFR inhibition has no approved role in advanced HCC, esophagogastric, and pancreatic malignancies. Phase II studies of cetuximab-chemotherapy combinations in advanced cholangiocarcinoma appear promising but randomized phase III data are lacking. Aside from CRC, VEGF inhibition may have use in HCC though it appears unhelpful in pancreatic malignancies. The data in esophagogastric cancers are mixed. Although bevacizumab did not show the improvement in outcomes, ramucirumab demonstrated the survival benefit in a heavily pre-treated patient population with advanced gastric cancer (REGARD) [67], which suggests that alternative (and possibly more intense) VEGF pathway inhibition can improve outcomes, especially when combined with chemotherapy [68]. HER2 inhibition has a defined role in HER2+ esophagogastric malignancies. Continued HER2 inhibition post-progression and combined HER2 blockade are areas of ongoing interest.

MSI-H CRC represents a distinct CRC subtype characterized by TAA expression that elicit a strong local (CD8+ T-cell infiltrates and peritumoral lymphoid nodules) host immune response [104] [105]. Immune checkpoints (PD-1 and CTLA-4) inhibitors may circumvent immune evasion that contributes to distant spread and the results of NCT01876511 (PD-1 in MSI-H CRC) and CheckMate 142/NCT01928394 (PD-1/CTLA-4 combination in MSI-H CRC) are eagerly awaited. These observations also provide a strong mechanistic rationale for using a peri-operative neoadjuvant approach in stage II/III MSI-H CRC.

Although many GI malignancies have defined TAA, prior vaccine trials were largely negative. Current vaccine studies are utilizing novel delivery systems [CEA expressing virus-like replicon particles (VRP)]; immunomodulatory strategies (low-dose metronomic cyclophosphamide); and are focusing on more immunogenic subtypes of GI malignancies (MSI-H CRC).

Recent trials have validated diverse immunotherapeutic approaches in GI malignancies beyond MoAbs inhibiting EGFR/VEGF. Existing MoAbs are being exploited in alternative settings and novel vaccine strategies are being developed. Immunotherapy is poised at the forefront of adjuvant, neoadjuvant and advanced approaches for the treatment and eradication of GI malignancies.

\section{References}

[1] Bujas, T., Marusic, Z., Balja, M.P., Mijic, A., Kruslin, B. and Tomas, D. (2011) MAGE-A3/4 and NY-ESO-1 Antigens Expression in Metastatic Esophageal Squamous Cell Carcinoma. European Journal of Histochemistry, 55, e7.

[2] Forghanifard, M.M., Gholamin, M., Farshchian, M., Moaven, O. and Memar, B., et al. (2011) Cancer-Testis Gene Expression Profiling in Esophageal Squamous Cell Carcinoma: Identification of Specific Tumor Marker and Potential Targets for Immunotherapy. Cancer Biology \& Therapy, 12, 191-197. http://dx.doi.org/10.4161/cbt.12.3.15949

[3] Ross, J.S. (2011) Update on HER2 Testing for Breast and Upper Gastrointestinal Tract Cancers. Biomarkers in Medi- 
cine, 5, 307-318. http://dx.doi.org/10.2217/bmm.11.31

[4] Lepisto, A.J., Moser, A.J., Zeh, H., Lee, K., Bartlett, D., et al. (2008) A Phase I/II Study of a MUC1 Peptide Pulsed Autologous Dendritic Cell Vaccine as Adjuvant Therapy in Patients with Resected Pancreatic and Biliary Tumors. Cancer Therapy, 6, 955-964.

[5] Pecher, G., Haring, A., Kaiser, L. and Thiel, E. (2002) Mucin Gene (MUC1) Transfected Dendritic Cells as Vaccine: Results of a Phase I/II Clinical Trial. Cancer Immunology, Immunotherapy, 51, 669-673. http://dx.doi.org/10.1007/s00262-002-0317-z

[6] Johnston, F.M., Tan, M.C., Tan Jr, B.R., Porembka, M.R., Brunt, E.M., et al. (2009) Circulating Mesothelin Protein and Cellular Antimesothelin Immunity in Patients with Pancreatic Cancer. Clinical Cancer Research, 15, 6511-5618. http://dx.doi.org/10.1158/1078-0432.CCR-09-0565

[7] Butterfield, L.H. (2004) Immunotherapeutic Strategies for Hepatocellular Carcinoma. Gastroenterology, 127, S232S241. http://dx.doi.org/10.1053/j.gastro.2004.09.038

[8] Evdokimova, V.N. and Butterfield, L.H. (2008) Alpha-Fetoprotein and Other Tumour-Associated Antigens for Immunotherapy of Hepatocellular Cancer. Expert Opinion on Biological Therapy, 8, 325-336. http://dx.doi.org/10.1517/14712598.8.3.325

[9] Conry, R.M., Curiel, D.T., Strong, T.V., Moore, S.E., Allen, K.O., et al. (2002) Safety and Immunogenicity of a DNA Vaccine Encoding Carcinoembryonic Antigen and Hepatitis B Surface Antigen in Colorectal Carcinoma Patients. Clinical Cancer Research, 8, 2782-2387.

[10] Marshall, J.L., Gulley, J.L., Arlen, P.M., Beetham, P.K., Tsang, K.Y., et al. (2005) Phase I Study of Sequential Vaccinations with Fowlpox-CEA(6D)-TRICOM Alone and Sequentially with Vaccinia-CEA(6D)-TRICOM, with and without Granulocyte-Macrophage Colony-Stimulating Factor, in Patients with Carcinoembryonic Antigen-Expressing Carcinomas. Journal of Clinical Oncology, 23, 720-731. http://dx.doi.org/10.1200/JCO.2005.10.206

[11] Kaufman, H.L., Lenz, H.J., Marshall, J., Singh, D., Garett, C., et al. (2008) Combination Chemotherapy and ALVACCEA/B7.1 Vaccine in Patients with Metastatic Colorectal Cancer. Clinical Cancer Research, 14, 4843-4849. http://dx.doi.org/10.1158/1078-0432.CCR-08-0276

[12] Hörig, H., Lee, D.S., Conkright, W., Divito, J., Hasson, H., et al. (2000) Phase I Clinical Trial of a Recombinant Canarypoxvirus (ALVAC) Vaccine Expressing Human Carcinoembryonic Antigen and the B7.1 Co-Stimulatory Molecule. Cancer Immunology, Immunotherapy, 49, 504-514. http://dx.doi.org/10.1007/s002620000146

[13] Schmitz-Winnenthal, F.H., Volk, C., Z’graggen, K., Galindo, L., Nummer, D., et al. (2005) High Frequencies of Functional Tumor-Reactive T Cells in Bone Marrow and Blood of Pancreatic Cancer Patients. Cancer Research, 65, 1007910087. http://dx.doi.org/10.1158/0008-5472.CAN-05-1098

[14] Amedei, A., Niccolai, E., Bella, C.D., Cianchi, F., Trallori, G., et al. (2009) Characterization of Tumor Antigen Peptide-Specific T Cells Isolated from the Neoplastic Tissue of Patients with Gastric Adenocarcinoma. Cancer Immunology, Immunotherapy, 58, 1819-1830. http://dx.doi.org/10.1007/s00262-009-0693-8

[15] Gabitass, R.F., Annels, N.E., Stocken, D.D., Pandha, H.A. and Middleton, G.W. (2011) Elevated Myeloid-Derived Suppressor Cells in Pancreatic, Esophageal and Gastric Cancer Are an Independent Prognostic Factor and Are Associated with Significant Elevation of the Th2 Cytokine Interleukin-13. Cancer Immunology, Immunotherapy, 60, 1419-1430. http://dx.doi.org/10.1007/s00262-011-1028-0

[16] Mundy-Bosse, B.L., Young, G.S., Bauer, T., Binkley, E., Bloomston, M., et al. (2011) Distinct Myeloid Suppressor Cell Subsets Correlate with Plasma IL-6 and IL-10 and Reduced Interferon-Alpha Signaling in CD4+ T Cells from Patients with GI Malignancy. Cancer Immunology, Immunotherapy, 60, 1269-1279. http://dx.doi.org/10.1007/s00262-011-1029-z

[17] Schubbert, S., Shannon, K. and Bollag, G. (2007) Hyperactive Ras in Developmental Disorders and Cancer. Nature Reviews Cancer, 7, 295-308. http://dx.doi.org/10.1038/nrc2109

[18] Kranenburg, O. (2005) The KRAS Oncogene: Past, Present, and Future. Biochimica et Biophysica Acta, 1756, 81-82.

[19] Vogelstein, B. and Kinzler, K.W. (2004) Cancer Genes and the Pathways They Control. Nature Medicine, 10, $789-799$. http://dx.doi.org/10.1038/nm1087

[20] Jonker, D.J., O’Callaghan, C.J., Karapetis, C.S., Zalcberg, J.R., Tu, D., et al. (2007) Cetuximab for the Treatment of Colorectal Cancer. The New England Journal of Medicine, 357, 2040-2048. http://dx.doi.org/10.1056/NEJMoa071834

[21] Karapetis, C.S., Khambata-Ford, S., Jonker, D.J., O’Callaghan, C.J., Tu, D., et al. (2008) K-ras Mutations and Benefit from Cetuximab in Advanced Colorectal Cancer. The New England Journal of Medicine, 359, 1757-1765. http://dx.doi.org/10.1056/NEJMoa0804385

[22] Van Cutsem, E., Köhne, C.H., Hitre, E., Zaluski, J., Chien, C.R.C., et al. (2009) Cetuximab and Chemotherapy as Initial Treatment for Metastatic Colorectal Cancer. The New England Journal of Medicine, 360, 1408-1417. http://dx.doi.org/10.1056/NEJMoa0805019 
[23] Van Cutsem, E., Köhne, C.H., Láng, I., Folprecht, G., Nowacki, M.P., et al. (2011) Cetuximab plus Irinotecan, Fluorouracil, and Leucovorin as First-Line Treatment for Metastatic Colorectal Cancer: Updated Analysis of Overall Survival According to Tumor KRAS and BRAF Mutation Status. Journal of Clinical Oncology, 29, 2011-2019. http://dx.doi.org/10.1200/JCO.2010.33.5091

[24] Bokemeyer, C., Bondarenko, I., Makhson, A., Hartmann, J.T., Aparicio, J., et al. (2009) Fluorouracil, Leucovorin, and Oxaliplatin with and without Cetuximab in the First-Line Treatment of Metastatic Colorectal Cancer. Journal of Clinical Oncology, 27, 663-671. http://dx.doi.org/10.1200/JCO.2008.20.8397

[25] Bokemeyer, C., Bondarenko, I., Hartmann, J.T., de Braud, F., Schuch, G., et al. (2011) Efficacy According to Biomarker Status of Cetuximab plus FOLFOX-4 as First-Line Treatment for Metastatic Colorectal Cancer: The OPUS Study. Annals of Oncology, 22, 1535-1546. http://dx.doi.org/10.1093/annonc/mdq632

[26] Bokemeyer, C., Van Cutsem, E., Rougier, P., Ciardiello, F., Heeger, S., et al. (2012) Addition of Cetuximab to Chemotherapy as First-Line Treatment for KRAS Wild-Type Metastatic Colorectal Cancer: Pooled Analysis of the CRYSTAL and OPUS Randomised Clinical Trials. European Journal of Cancer, 48, 1466-1475. http://dx.doi.org/10.1016/j.ejca.2012.02.057

[27] Maughan, T.S., Adams, R.A., Smith, C.G., Meade, A.M., Seymour, M.T., et al. (2011) Addition of Cetuximab to Oxaliplatin-Based First-Line Combination Chemotherapy for Treatment of Advanced Colorectal Cancer: Results of the Randomised Phase 3 MRC COIN Trial. The Lancet, 377, 2103-2114. http://dx.doi.org/10.1016/S0140-6736(11)60613-2

[28] Tveit, K.M., Guren, T., Glimelius, B., Pfeiffer, P., Sorbye, H., et al. (2012) Phase III Trial of Cetuximab with Continuous or Intermittent Fluorouracil, Leucovorin, and Oxaliplatin (Nordic FLOX) versus FLOX Alone in First-Line Treatment of Metastatic Colorectal Cancer: the NORDIC-VII Study. Journal of Clinical Oncology, 30, 1755-1762. http://dx.doi.org/10.1200/JCO.2011.38.0915

[29] Sobrero, A.F., Maurel, J., Fehrenbacher, L., Scheithauer, W., Abubakr, Y.A., et al. (2008) EPIC: Phase III Trial of Cetuximab plus Irinotecan after Fluoropyrimidine and Oxaliplatin Failure in Patients with Metastatic Colorectal Cancer. Journal of Clinical Oncology, 26, 2311-2319. http://dx.doi.org/10.1200/JCO.2007.13.1193

[30] Price, T., Peeters, M., Kim, T.W., Li, J., Cascinu, S., et al. (2013) ASPECCT: A Randomized, Multicenter, Open-Label, Phase 3 Study of Panitumumab vs Cetuximab for Previously Treated Wild-Type KRAS Metastatic Colorectal Cancer. 2013 European Cancer Congress, 4 November 2013, Amsterdam, Abstract LBA18.

[31] Heinemann, V., von Weikerstha, L.F., Decker, T., Vehling-Kaiser, U., Kiani, A., et al. (2013) Randomized Comparison of FOLFIRI plus Cetuximab versus FOLFIRI plus Bevacizumab as First-Line Treatment of KRAS Wild-Type Metastatic Colorectal Cancer: German AIO Study KRK-0306 (FIRE-3). 2013 ASCO Annual Meeting.

[32] Alberts, S.R., Sargent, D.J., Nair, S., Mahoney, M.R., Mooney, M., et al. (2012) Effect of Oxaliplatin, Fluorouracil, and Leucovorin with or without Cetuximab on Survival among Patients with Resected Stage III Colon Cancer: A Randomized Trial. JAMA, 307, 1383-1393. http://dx.doi.org/10.1001/jama.2012.385

[33] Taïeb, J., Tabernero, J., Mini, E., Subtil, F., Folprecht, G., et al. (2013) Subgroup Analyses Results of the PETACC8 Phase III Trial Comparing Adjuvant FOLFOX4 with or without Cetuximab (CTX) in Resected Stage III Colon Cancer (CC). 2013 ASCO Annual Meeting.

[34] Lordick, F., Kang, Y.K., Chung, H., Salman, P., Oh, S.C., et al. (2013) Capecitabine and Cisplatin with or without Cetuximab for Patients with Previously Untreated Advanced Gastric Cancer (EXPAND): A Randomised, Open-Label Phase 3 Trial. The Lancet Oncology, 14, 490-499. http://dx.doi.org/10.1016/S1470-2045(13)70102-5

[35] Philip, P.A., Benedetti, J., Corless, C.L., Wong, R., O’Reilly, E.M., et al. (2010) Phase III Study Comparing Gemcitabine plus Cetuximab versus Gemcitabine in Patients with Advanced Pancreatic Adenocarcinoma: Southwest Oncology Group-Directed Intergroup Trial S0205. Journal of Clinical Oncology, 28, 3605-3610. http://dx.doi.org/10.1200/JCO.2009.25.7550

[36] Van Cutsem, E., Peeters, M., Siena, S., Humblet, Y., Hendlisz, A., et al. (2007) Open-Label Phase III Trial of Panitumumab plus Best Supportive Care Compared with Best Supportive Care Alone in Patients with Chemotherapy-Refractory Metastatic Colorectal Cancer. Journal of Clinical Oncology, 25, 1658-1664. http://dx.doi.org/10.1200/JCO.2006.08.1620

[37] Douillard, J.Y., Siena, S., Cassidy, J., Tabernero, J., Burkes, R., et al. (2010) Randomized, Phase III Trial of Panitumumab with Infusional Fluorouracil, Leucovorin, and Oxaliplatin (FOLFOX4) versus FOLFOX4 Alone as First-Line Treatment in Patients with Previously Untreated Metastatic Colorectal Cancer: The PRIME Study. Journal of Clinical Oncology, 28, 4697-4705. http://dx.doi.org/10.1200/JCO.2009.27.4860

[38] Peeters, M., Price, T.J., Cervantes, A., Sobrero, A.F., Ducreux, M., et al. (2010) Randomized Phase III Study of Panitumumab with Fluorouracil, Leucovorin, and Irinotecan (FOLFIRI) Compared with FOLFIRI Alone as Second-Line Treatment in Patients with Metastatic Colorectal Cancer. Journal of Clinical Oncology, 28, 4706-4713. http://dx.doi.org/10.1200/JCO.2009.27.6055 
[39] Seymour, M.T., Brown, S.R., Middleton, G., Maughan, T., Richman, S., et al. (2013) Panitumumab and Irinotecan versus Irinotecan Alone for Patients with KRAS Wild-Type, Fluorouracil-Resistant Advanced Colorectal Cancer (PICCOLO): A Prospectively Stratified Randomised Trial. The Lancet Oncology, 14, 749-759. http://dx.doi.org/10.1016/S1470-2045(13)70163-3

[40] Waddell, T., Chau, I., Cunningham, D., Gonzalez, D., Okines, A.F.C., et al. (2013) Epirubicin, Oxaliplatin, and Capecitabine with or without Panitumumab for Patients with Previously Untreated Advanced Oesophagogastric Cancer (REAL3): A Randomised, Open-Label Phase 3 Trial. The Lancet Oncology, 14, 481-489. http://dx.doi.org/10.1016/S1470-2045(13)70096-2

[41] Basu, G.D., Xiu, J., Arguello, D., Feldman, R.A., Millis, S.Z., et al. (2014) Prevalence of KRAS, BRAF, NRAS, PIK3CA, and PTEN Alterations in Colorectal Cancer: Analysis of a Large International Cohort of 5,900 Patients. 2013 ASCO Annual Meeting.

[42] National Comprehensive Cancer Network (2014) Colon Cancer (Version 3). http://www.nccn.org/professionals/physician_gls/pdf/colon.pdf

[43] O’Neil, B.H., Allen, R., Spigel, D.R., Stinchcombe, T.E., Moore, D.T., et al. (2007) High Incidence of Cetuximab-Related Infusion Reactions in Tennessee and North Carolina and the Association with Atopic History. Journal of Clinical Oncology, 25, 3644-3648. http://dx.doi.org/10.1200/JCO.2007.11.7812

[44] Metges, J., Raoul, J., Achour, N., Capitain, O., Gourlaouen, A., et al. (2010) PANERB Study: Panitumumab after Cetuximab-Based Regimen Failure. 2013 ASCO Annual Meeting.

[45] Wadlow, R.C., Hezel, A.F., Abrams, T.F., Blaszkowskya, L.S., Fuchs, C.S., et al. (2012) Panitumumab in Patients with KRAS Wild-Type Colorectal Cancer after Progression on Cetuximab. The Oncologist, 17, e14-e34. http://dx.doi.org/10.1634/theoncologist.2011-0452

[46] Lee, S.H., Lee, J.W., Soung, Y.H., Kim, H.S., Park, W.S., et al. (2003) BRAF and KRAS Mutations in Stomach Cancer. Oncogene, 22, 6942-6945. http://dx.doi.org/10.1038/sj.onc.1206749

[47] Rubovszky, G., Láng, I., Ganofszky, E., Horváth, Z., Juhos, É., et al. (2013) Cetuximab, Gemcitabine and Capecitabine in Patients with Inoperable Biliary Tract Cancer: A Phase 2 Study. European Journal of Cancer, 49, 3806-3812. http://dx.doi.org/10.1016/j.ejca.2013.07.143

[48] Borbath, I., Ceratti, A., Verslype, C., Demols, A., Delaunoit, T., et al. (2013) Combination of Gemcitabine and Cetuximab in Patients with Advanced Cholangiocarcinoma: A Phase II Study Of the Belgian Group of Digestive Oncology. Annals of Oncology, 24, 2824-2829. http://dx.doi.org/10.1093/annonc/mdt337

[49] Jensen, L.H., Lindebjerg, J., Ploen, J., Hansen, T.F. and Jakobsen, A. (2012) Phase II Marker-Driven Trial of Panitumumab and Chemotherapy in KRAS Wild-Type Biliary Tract Cancer. Annals of Oncology, 23, 2341-2346. http://dx.doi.org/10.1093/annonc/mds008

[50] Sohal, D.P., Mykulowycz, K., Uehara, T., Teitelbaum, U.R., Damjanov, N., et al. (2013) A Phase II Trial of Gemcitabine, Irinotecan and Panitumumab in Advanced Cholangiocarcinoma. Annals of Oncology, 24, 3061-3065. http://dx.doi.org/10.1093/annonc/mdt416

[51] Zhu, A.X., Stuart, K., Blaszkowsky, L.S., Muzikansky M.A.A., Reitberg, D.P., et al. (2007) Phase 2 Study of Cetuximab in Patients with Advanced Hepatocellular Carcinoma. Cancer, 110, 581-589. http://dx.doi.org/10.1002/cncr.22829

[52] Asnacios, A., Fartoux, L., Romano, O., Tesmoingt, C., Louafi, S.S., et al. (2008) Gemcitabine plus Oxaliplatin (GEMOX) Combined with Cetuximab in Patients with Progressive Advanced Stage Hepatocellular Carcinoma: Results of a Multicenter Phase 2 Study. Cancer, 112, 2733-2739. http://dx.doi.org/10.1002/cncr.23489

[53] Sanoff, H.K., Bernard, S., Goldberg, R.M., Morse, M.A., Garcia, R., et al. (2011) Phase II Study of Capecitabine, Oxaliplatin, and Cetuximab for Advanced Hepatocellular Carcinoma. Gastrointestinal Cancer Research, 4, 78-83.

[54] Hanahan, D. and Weinberg, R.A. (2011) Hallmarks of Cancer: The Next Generation. Cell, 144, 646-674. http://dx.doi.org/10.1016/j.cell.2011.02.013

[55] Jain, R.K. (2013) Normalizing Tumor Microenvironment to Treat Cancer: Bench to Bedside to Biomarkers. Journal of Clinical Oncology, 31, 2205-2218. http://dx.doi.org/10.1200/JCO.2012.46.3653

[56] Hurwitz, H., Fehrenbacher, L., Novotny, W., Cartwright, T., Hainsworth, J., et al. (2004) Bevacizumab plus Irinotecan, Fluorouracil, and Leucovorin for Metastatic Colorectal Cancer. The New England Journal of Medicine, 350, 23352342. http://dx.doi.org/10.1056/NEJMoa032691

[57] Hurwitz, H.I., Fehrenbacher, L., Hainsworth, J.D., Heim, W., Berlin, J., et al. (2005) Bevacizumab in Combination with Fluorouracil and Leucovorin: An Active Regimen for First-Line Metastatic Colorectal Cancer. Journal of Clinical Oncology, 23, 3502-3508. http://dx.doi.org/10.1200/JCO.2005.10.017

[58] Giantonio, B.J., Catalano, P.J., Meropol, N.J., O’Dwyer, P.J., Mitchell, E.P., et al. (2007) Bevacizumab in Combination with Oxaliplatin, Fluorouracil, and Leucovorin (FOLFOX4) for Previously Treated Metastatic Colorectal Cancer: 
Results from the Eastern Cooperative Oncology Group Study E3200. Journal of Clinical Oncology, 25, 1539-1544. http://dx.doi.org/10.1200/JCO.2006.09.6305

[59] Saltz, L.B., Clarke, S., Díaz-Rubio, E., Scheithauer, W., Figer, A., et al. (2008) Bevacizumab in Combination with Oxaliplatin-Based Chemotherapy as First-Line Therapy in Metastatic Colorectal Cancer: A Randomized Phase III Study. Journal of Clinical Oncology, 26, 2013-2019. http://dx.doi.org/10.1200/JCO.2007.14.9930

[60] Bennouna, J., Sastre, J., Arnold, D., Österlund, P., Greil, R., et al. (2013) Continuation of Bevacizumab after First Progression in Metastatic Colorectal Cancer (ML18147): A Randomised Phase 3 Trial. The Lancet Oncology, 14, $29-37$. http://dx.doi.org/10.1016/S1470-2045(12)70477-1

[61] Falcone, A., Cremolini, C., Masi, G., Lonardi, S., Zagonel, V., et al. (2013) FOLFOXIRI/Bevacizumab (Bev) versus FOLFIRI/Bev as First-Line Treatment in Unresectable Metastatic Colorectal Cancer (mCRC) Patients (Pts): Results of the Phase III TRIBE Trial by GONO Group. 2013 ASCO Annual Meeting.

[62] Allegra, C.J., Yothers, G., O’Connell, M.J., Sharif, S., Petrelli, N.J., et al. (2011) Phase III Trial Assessing Bevacizumab in Stages II and III Carcinoma of the Colon: Results of NSABP Protocol C-08. Journal of Clinical Oncology, 29, 11-16. http://dx.doi.org/10.1200/JCO.2010.30.0855

[63] de Gramont, A., Van Cutsem, E., Schmoll, H.J., Tabernero, J., Clarke S., et al. (2012) Bevacizumab plus OxaliplatinBased Chemotherapy as Adjuvant Treatment for Colon Cancer (AVANT): A Phase 3 Randomised Controlled Trial. The Lancet Oncology, 13, 1225-1233. http://dx.doi.org/10.1016/S1470-2045(12)70509-0

[64] Ohtsu, A., Shah, M.A., Van Cutsem, E., Rha, S.Y., Sawaki, A., et al. (2011) Bevacizumab in Combination with Chemotherapy as First-Line Therapy in Advanced Gastric Cancer: A Randomized, Double-Blind, Placebo-Controlled Phase III Study. Journal of Clinical Oncology, 29, 3968-3976. http://dx.doi.org/10.1200/JCO.2011.36.2236

[65] Shen, L., Li, J., Xu, J., Pan, H., Dai, G., et al. (2014) Bevacizumab plus Capecitabine and Cisplatin in Chinese Patients with Inoperable Locally Advanced or Metastatic Gastric or Gastroesophageal Junction Cancer: Randomized, DoubleBlind, Phase III Study (AVATAR Study). Gastric Cancer, Published Online. http://dx.doi.org/10.1007/s10120-014-0351-5

[66] Kindler, H.L., Niedzwiecki, D., Hollis, D., Sutherland, S., Schrag, D., et al. (2010) Gemcitabine plus Bevacizumab Compared with Gemcitabine plus Placebo in Patients with Advanced Pancreatic Cancer: Phase III Trial of the Cancer and Leukemia Group B (CALGB 80303). Journal of Clinical Oncology, 28, 3617-3622. http://dx.doi.org/10.1200/JCO.2010.28.1386

[67] Fuchs, C.S., Tomasek, J., Yong, C.J., Dumitru, F., Passalacqua, R., et al. (2014) Ramucirumab Monotherapy for Previously Treated Advanced Gastric or Gastro-Oesophageal Junction Adenocarcinoma (REGARD): An International, Randomised, Multicentre, Placebo-Controlled, Phase 3 Trial. The Lancet, 383, 31-39. http://dx.doi.org/10.1016/S0140-6736(13)61719-5

[68] Wilke, H., Cutsem, E.V., Oh, S.C., Bodoky, G., Shimada, Y., et al. (2014) RAINBOW: A Global, Phase III, Randomized, Double-Blind Study of Ramucirumab plus Paclitaxel versus Placebo plus Paclitaxel in the Treatment of Metastatic Gastroesophageal Junction (GEJ) and Gastric Adenocarcinoma Following Disease Progression on First-Line Platinum- and Fluoropyrimidine-Containing Combination Therapy Rainbow IMCL CP12-0922 (I4T-IE-JVBE). 2014 ASCO Annual Meeting.

[69] Van Cutsem, E., Tabernero, J., Lakomy, R., Prenen, H., Prausová, J., et al. (2012) Addition of Aflibercept to Fluorouracil, Leucovorin, and Irinotecan Improves Survival in a Phase III Randomized Trial in Patients with Metastatic Colorectal Cancer Previously Treated with an Oxaliplatin-Based Regimen. Journal of Clinical Oncology, 30, 34993506. http://dx.doi.org/10.1200/JCO.2012.42.8201

[70] Rougier, P., Riess, H., Manges, R., Karasek, P., Humblet, Y., et al. (2013) Randomised, Placebo-Controlled, DoubleBlind, Parallel-Group Phase III Study Evaluating Aflibercept in Patients Receiving First-Line Treatment with Gemcitabine for Metastatic Pancreatic Cancer. European Journal of Cancer, 49, 2633-2642. http://dx.doi.org/10.1016/j.ejca.2013.04.002

[71] Pericay, C., Folprecht, G., Saunders, M., Thomas, A, Roh, J.K., et al. (2012) Phase 2 Randomized, Noncomparative Open-Label Study of Aflibercept and Modified FOLFOX6 in the First Line Treatment of Metastatic Colorectal Cancer (AFFIRM). Annals of Oncology, 23, iv5-iv18.

[72] Smyth, E.C., Langley, R.E., Stenning, S.P., et al. (2013) ST03: A Randomized Trial of Perioperative Epirubicin, Cisplatin plus Capecitabine (ECX) with or without Bevacizumab (B) in Patients (Pts) with Operable Gastric, Esophagogastric Junction (OGJ), or Lower Esophageal Adenocarcinoma. 2013 ASCO Annual Meeting.

[73] Sun, W., Sohal, D., Haller, D.G., Mykulowycz, K., Rosen, M., et al. (2011) Phase 2 Trial of Bevacizumab, Capecitabine, and Oxaliplatin in Treatment of Advanced Hepatocellular Carcinoma. Cancer, 117, 3187-3192. http://dx.doi.org/10.1002/cncr.25889

[74] Zhu, A.X., Blaszkowsky, L.S., Ryan, D.P., Clark, J.W., Muzikansky, A., et al. (2006) Phase II Study of Gemcitabine and Oxaliplatin in Combination with Bevacizumab in Patients with Advanced Hepatocellular Carcinoma. Journal of 
Clinical Oncology, 24, 1898-1903. http://dx.doi.org/10.1200/JCO.2005.04.9130

[75] Schoppmann, S.F., Jesch, B., Friedrich, J., Wrba, F., Schultheis, A., et al. (2010) Expression of Her-2 in Carcinomas of the Esophagus. American Journal of Surgical Pathology, 34, 1868-1873. http://dx.doi.org/10.1097/PAS.0b013e3181f8be17

[76] Hu, Y., Bandla, S., Godfrey, T.E., Tan, D., Luketich, J.D., et al. (2011) HER2 Amplification, Overexpression and Score Criteria in Esophageal Adenocarcinoma. Modern Pathology, 24, 899-907. http://dx.doi.org/10.1038/modpathol.2011.47

[77] Yoon, H.H., Shi, Q., Sukov, W.R., Wiktor, A.E., Khan, M., et al. (2012) Association of HER2/ErbB2 Expression and Gene Amplification with Pathologic Features and Prognosis in Esophageal Adenocarcinomas. Clinical Cancer Research, 18, 546-554. http://dx.doi.org/10.1158/1078-0432.CCR-11-2272

[78] Bang, Y., Chung, H., Xu, J., Lordick, F., Sawaki, A., et al. (2009) Pathological Features of Advanced Gastric Cancer (GC): Relationship to Human Epidermal Growth Factor Receptor 2 (HER2) Positivity in the Global Screening Programme of the ToGA Trial. 2009 ASCO Annual Meeting.

[79] Bang, Y.J., Van Cutsem, E., Feyereislova, A., Chung, H.C., Shen, L., et al. (2010) Trastuzumab in Combination with Chemotherapy versus Chemotherapy Alone for Treatment of HER2-Positive Advanced Gastric or Gastro-Oesophageal Junction Cancer (ToGA): A Phase 3, Open-Label, Randomised Controlled Trial. The Lancet, 376, 687-697. http://dx.doi.org/10.1016/S0140-6736(10)61121-X

[80] Leyland-Jones, B., Colomer, R., Trudeau, M.E., Wardley, A., Latreille, J., et al. (2010) Intensive Loading Dose of Trastuzumab Achieves Higher-than-Steady-State Serum Concentrations and Is Well Tolerated. Journal of Clinical Oncology, 28, 960-966. http://dx.doi.org/10.1200/JCO.2009.23.1910

[81] Verma, S., Miles, D., Gianni, L., Krop, I.E., Welslau, M., et al. (2012) Trastuzumab Emtansine for HER2-Positive Advanced Breast Cancer. The New England Journal of Medicine, 367, 1783-1791. http://dx.doi.org/10.1056/NEJMoa1209124

[82] Schneeweiss, A., Chia, S., Hickish, T., Harvey, V., Eniu, A., et al. (2013) Pertuzumab plus Trastuzumab in Combination with Standard Neoadjuvant Anthracycline-Containing and Anthracycline-Free Chemotherapy Regimens in Patients with HER2-Positive Early Breast Cancer: A Randomized Phase II Cardiac Safety Study (TRYPHAENA). Annals of Oncology, 24, 2278-2284. http://dx.doi.org/10.1093/annonc/mdt182

[83] Swain, S.M., Kim, S.B., Cortés, J., Ro, J., Semiglazov, V., et al. (2013) Pertuzumab, Trastuzumab, and Docetaxel for HER2-Positive Metastatic Breast Cancer (CLEOPATRA Study): Overall Survival Results from a Randomised, Double-Blind, Placebo-Controlled, Phase 3 Study. The Lancet Oncology, 14, 461-471. http://dx.doi.org/10.1016/S1470-2045(13)70130-X

[84] Chen, L. and Flies, D.B. (2013) Molecular Mechanisms of T Cell Co-Stimulation and Co-Inhibition. Nature Reviews Immunology, 13, 227-242. http://dx.doi.org/10.1038/nri3405

[85] Parry, R.V., Chemnitz, J.M., Frauwirth, K.A., Lanfranco, A.R., Braunstein, I., et al. (2005) CTLA-4 and PD-1 Receptors Inhibit T-Cell Activation by Distinct Mechanisms. Molecular and Cellular Biology, 25, 9543-9553. http://dx.doi.org/10.1128/MCB.25.21.9543-9553.2005

[86] Hodi, F.S., O’Day, S.J., McDermott, D.F., Weber, R.W., Sosman, J.A., et al. (2010) Improved Survival with Ipilimumab in Patients with Metastatic Melanoma. The New England Journal of Medicine, 363, 711-723. http://dx.doi.org/10.1056/NEJMoa1003466

[87] Robert, C., Thomas, L., Bondarenko, I., O’Day, S., Weber, J., et al. (2011) Ipilimumab plus Dacarbazine for Previously Untreated Metastatic Melanoma. The New England Journal of Medicine, 364, 2517-2526. http://dx.doi.org/10.1056/NEJMoa1104621

[88] Ribas, A., Kefford, R., Marshall, M.A., Punt, C.J.A., Haanen, J.B., et al. (2013) Phase III Randomized Clinical Trial Comparing Tremelimumab with Standard-of-Care Chemotherapy in Patients with Advanced Melanoma. Journal of Clinical Oncology, 31, 616-622. http://dx.doi.org/10.1200/JCO.2012.44.6112

[89] Lipson, E.J., Sharfman, W.H., Drake, C.G., Wollner, I., Taube, J.M., et al. (2013) Durable Cancer Regression OffTreatment and Effective Reinduction Therapy with an Anti-PD-1 Antibody. Clinical Cancer Research, 19, 462-468. http://dx.doi.org/10.1158/1078-0432.CCR-12-2625

[90] Banerjea, A., Ahmed, S., Hands, R.E., Huang, F., Han, X., et al. (2004) Colorectal Cancers with Microsatellite Instability Display mRNA Expression Signatures Characteristic of Increased Immunogenicity. Molecular Cancer, 3, 21. http://dx.doi.org/10.1186/1476-4598-3-21

[91] Banerjea, A., Hands, R.E., Powar, M.P., Bustin, S.A. and Dorudi, S. (2009) Microsatellite and Chromosomal Stable Colorectal Cancers Demonstrate Poor Immunogenicity and Early Disease Recurrence. Colorectal Disease, 11, 601-608. http://dx.doi.org/10.1111/j.1463-1318.2008.01639.x

[92] Rosenberg, S.A., Yang, J.C. and Restifo, N.P. (2004) Cancer Immunotherapy: Moving beyond Current Vaccines. Na- 
ture Medicine, 10, 909-915. http://dx.doi.org/10.1038/nm1100

[93] Klebanoff, C.A., Acquavella, N., Yu, Z. and Restifo, N.P. (2011) Therapeutic Cancer Vaccines: Are We There Yet? Immunological Reviews, 239, 27-44. http://dx.doi.org/10.1111/j.1600-065X.2010.00979.X

[94] Gunturu, K.S., Rossi, G.R. and Saif, M.W. (2013) Immunotherapy Updates in Pancreatic Cancer: Are We There Yet? Therapeutic Advances in Medical Oncology, 5, 81-89. http://dx.doi.org/10.1177/1758834012462463

[95] Regine, W.F., Winter, K.A., Abrams, R., Safran, H., Hoffman, J.P., et al. (2011) Fluorouracil-Based Chemoradiation with Either Gemcitabine or Fluorouracil Chemotherapy after Resection of Pancreatic Adenocarcinoma: 5-Year Analysis of the U.S. Intergroup/RTOG 9704 Phase III Trial. Annals of Surgical Oncology, 18, 1319-1326. http://dx.doi.org/10.1245/s10434-011-1630-6

[96] Hardacre, J.M., Mulcahy, M., Small, W., Talamonti, M., Obel, J., et al. (2013) Addition of Algenpantucel-L Immunotherapy to Standard Adjuvant Therapy for Pancreatic Cancer: A Phase 2 Study. Journal of Gastrointestinal Surgery, 17, 94-100.

[97] Nemunaitis, J. (2005) Vaccines in Cancer: GVAX ${ }^{\circledR}$, a GM-CSF Gene Vaccine. Expert Review of Vaccines, 4, $259-274$. http://dx.doi.org/10.1586/14760584.4.3.259

[98] Royal, R.E., Levy, C., Turner, K., Mathur, A., Hughes, M., et al. (2010) Phase 2 Trial of Single Agent Ipilimumab (Anti-CTLA-4) for Locally Advanced or Metastatic Pancreatic Adenocarcinoma. Journal of Immunotherapy, 33, 828833. http://dx.doi.org/10.1097/CJI.0b013e3181eec14c

[99] Lutz, E., Yeo, C.J., Lillemoe, K.D., Biedrzycki, B., Kobrin, B., Herman, J., et al. (2011) A Lethally Irradiated Allogeneic Granulocyte-Macrophage Colony Stimulating Factor-Secreting Tumor Vaccine for Pancreatic Adenocarcinoma. A Phase II Trial of Safety, Efficacy, and Immune Activation. Annals of Surgery, 253, 328-335. http://dx.doi.org/10.1097/SLA.0b013e3181fd271c

[100] Vonderheide, R.H. and Bayne, L.J. (2013) Inflammatory Networks and Immune Surveillance of Pancreatic Carcinoma. Current Opinion in Immunology, 25, 200-205. http://dx.doi.org/10.1016/j.coi.2013.01.006

[101] Le, D.T., Lutz, E., Uram, J.N., Sugar, E.A., Onners, B., et al. (2013) Evaluation of Ipilimumab in Combination with Allogeneic Pancreatic Tumor Cells Transfected with a GM-CSF Gene in Previously Treated Pancreatic Cancer. Journal of Immunotherapy, 36, 382-389. http://dx.doi.org/10.1097/CJI.0b013e31829fb7a2

[102] Takayama, T., Sekine, T., Makuuchi, M., Yamasaki, S., Kosuge, T., et al. (2000) Adoptive Immunotherapy to Lower Postsurgical Recurrence Rates of Hepatocellular Carcinoma: A Randomised Trial. The Lancet, 356, 802-807. http://dx.doi.org/10.1016/S0140-6736(00)02654-4

[103] El Ansary, M., Mogawer, S., Elhamid, S.A., Alwakil, S., Aboelkasem, F., et al. (2013) Immunotherapy by Autologous Dendritic Cell Vaccine in Patients with Advanced HCC. Journal of Cancer Research and Clinical Oncology, 139, 3948. http://dx.doi.org/10.1007/s00432-012-1298-8

[104] Kloor, M., Michel, S. and Doeberitz, M.V.K. (2010) Immune Evasion of Microsatellite Unstable Colorectal Cancers. International Journal of Cancer, 127, 1001-1010. http://dx.doi.org/10.1002/ijc.25283

[105] Bauer, K., Nelius, N., Reuschenbach, M., Koch, M., Weitz, J., et al. (2013) T Cell Responses against Microsatellite Instability-Induced Frameshift Peptides and Influence of Regulatory T Cells in Colorectal Cancer. Cancer Immunology, Immunotherapy, 62, 27-37. http://dx.doi.org/10.1007/s00262-012-1303-8

[106] Van Cutsem, E., de Haas, S., Kang, Y.K., et al. (2012) Bevacizumab in Combination with Chemotherapy as First-Line Therapy in Advanced Gastric Cancer: A Biomarker Evaluation from the AVAGAST Randomized Phase III Trial. Journal of Clinical Oncology, 30, 2119-2127. 